OPEN ACCESS

Edited by:

Thierry Walzer,

UMR5308 Centre International de Recherche en Infectiologie

(CIRI), France

Reviewed by:

Carmelo Luci,

Institut National de la Santé et de la

Recherche Médicale

(INSERM), France

Cai Zhang,

Shandong University, China

*Correspondence:

Yongyan Chen

yychen08@ustc.edu.cn

Specialty section:

This article was submitted to

NK and Innate Lymphoid Cell Biology,

a section of the journa

Frontiers in Immunology

Received: 28 April 2020

Accepted: 09 June 2020

Published: 16 July 2020

Citation:

Chen Y and Tian Z (2020) Roles of Hepatic Innate and Innate-Like

Lymphocytes in Nonalcoholic Steatohepatitis.

Front. Immunol. 11:1500.

doi: 10.3389/fimmu.2020.01500

\section{Roles of Hepatic Innate and Innate-Like Lymphocytes in Nonalcoholic Steatohepatitis}

\author{
Yongyan Chen ${ }^{1,2 *}$ and Zhigang Tian ${ }^{1,2}$ \\ ${ }^{1}$ Hefei National Laboratory for Physical Sciences at Microscale, The CAS Key Laboratory of Innate Immunity and Chronic \\ Disease, Division of Molecular Medicine, School of Life Sciences, University of Science and Technology of China, Hefei, \\ China, ${ }^{2}$ Institute of Immunology, University of Science and Technology of China, Hefei, China
}

Nonalcoholic steatohepatitis (NASH), a progressive form of nonalcoholic fatty liver disease (NAFLD), is accompanied by steatosis, hepatocyte injury and liver inflammation, which has been a health problem in the world as one of the major high risk factors of cirrhosis and hepatocellular carcinoma (HCC). Complex immune responses involving T cells, B cells, Kupffer cells, monocytes, neutrophils, DCs and other innate lymphocytes account for the pathogenesis of NASH; however, the underlying mechanisms have not been clearly elucidated in detail. In the liver, innate and innate-like lymphocytes account for more than two-thirds of total lymphocytes and play an important role in maintaining the immune homeostasis. Therefore, their roles in the progression of NASH deserves investigation. In this review, we summarized murine NASH models for immunological studies, including the diet-induced NASH, chemical-induced NASH and genetic-induced $\mathrm{NASH}$. The role of innate and innate-like lymphocytes including NK cells, ILCs, NKT, $\gamma \delta \mathrm{T}$ and MAIT cells in the progression of NASH were elucidated. Further, the metabolic regulation of the innate immune response was addressed in consideration to explain the molecular mechanisms. Based on the findings of the reviewed studies, strategies of immune intervention are proposed to control the progression of $\mathrm{NASH}$.

Keywords: NASH, NK, ILC, NKT, $\gamma \delta$ T, MAIT

\section{INTRODUCTION}

Nonalcoholic steatohepatitis (NASH) is a kind of liver disease, as the progressive form of nonalcoholic fatty liver disease (NAFLD), accompanied with steatosis, hepatocyte injury and liver inflammation as a consequence of disordered lipid metabolism in the liver. The prevalence of NASH is estimated to be between 1.5 and $6.5 \%$ globally, and up to $30 \%$ in individuals with fatty liver (hepatic steatosis). NASH was initially characterized by the hepatocyte death caused by lipotoxicity (1-3). NASH has been a global health challenge, since it is one of the major risk factors for the development of liver cirrhosis and hepatocellular carcinoma (HCC) $(4,5)$. As a multifactorial disease, the precise pathogenesis of NASH has not been fully elucidated, which is considered to be attributable to excessive fatty acids, oxidative stress, lipid peroxidation, mitochondrial dysfunction and some other extra-hepatic factors such as dysfunctional adipose tissue and altered gut microbiota (6). NAFLD/NASH is strongly associated with obesity, and the risk is generally increased with the degree of obesity $(7,8)$. Additionally, metabolic syndrome, especially the presence of type 2 diabetes mellitus (T2DM), insulin resistance, dyslipidemia and 
hypertension are risk factors of NAFLD progression (9). Signals derived from adipose tissue such as FFA, adipokine imbalance, pro-inflammatory cytokines TNF- $\alpha /$ IL- 6 and insulin resistance promote the progression of NASH (10). The cross-talk between the gut and the liver including the microbiota modifications due to dysbiosis, intestinal permeability and metabolic endotoxemia are crucial events leading to NASH $(10,11)$. NAFLD is also featured with extra-hepatic manifestations as a risk factor for osteoporosis, thyroid dysfunction, chronic kidney disease, cardiovascular disease and colorectal cancer (12).

Accumulation of lipids and other lipid-derivatives in the liver affects hepatocytes, non-parenchymal hepatic cells and extra-hepatic cells. During the development of NASH, damaged hepatocytes evoke the immune responses by releasing various signals such as damage-associated molecular patterns (DAMPs) and pathogen-associated molecular patterns (PAMPs) to activate resident and recruited immune cells. Liver is an immunological organ that contains a large number of innate and adaptive immune cells; in particular, the largest populations of macrophages (Kupffer cells), natural killer (NK) cells, natural killer $\mathrm{T}(\mathrm{NKT})$ cells and $\gamma \delta \mathrm{T}$ cells. Complex immune responses are involved in the pathogenesis of NASH including $\mathrm{T}$ cells, B cells, Kupffer cells (KCs), monocytes, neutrophils, dendritic cells (DCs) and other innate lymphocytes (13). Non-parenchymal hepatic cells with immune functions such as liver sinusoidal endothelial cells (LSECs) and hepatic stellate cells (HSCs), also participate in the development of NASH. With the further understanding of the composition of immune cells in the liver, including the discovery of novel cell subsets such as liver-resident NK cells, innate lymphoid cells (ILCs) and mucosa-associated invariant T (MAIT), the immunopathological mechanisms of NASH are necessary to be further analyzed and recognized. In this review, we discuss the current progress in the immunopathogenesis of NASH, mainly focusing on the hepatic innate and innate-like lymphocytes including NK cells, ILCs, NKT cells, $\gamma \delta$ T cells and MAIT cells. Based on the understanding of the immunopathogenesis of this disease, therapeutic strategies are proposed to control NASH.

\section{MURINE NASH MODELS AND THEIR CHARACTERISTICS}

Hepatic steatosis can be induced by fat accumulation, virus infection, medications or genetic disorders in humans. Steatohepatitis induced by factors other than alcohol consumption, virus infection and medication induction belongs to NAFLD. Accordingly, murine NASH models mimicking the pathological features of human NASH are defined as dietinduced NASH, chemical-induced NASH and genetic-induced NASH. Each kind of model exhibits distinct characteristics (Table 1).

\section{Diet-Induced NASH}

Excessive free fatty acids (FFAs) that are not utilized by FFA oxidation and VLDL secretion, undergo re-esterification into
TGs, and TG accumulation leads to hepatic steatosis. Therefore, high fat, high fructose or high cholesterol diets are used to generate NASH models in mice. Dietary factors also play an important role in shaping the composition and diversity of gut microbiota as demonstrated in animal models of NAFLD, which contributed to the progression of NASH (35).

High fat diets (HFD) are used to induce hepatic steatosis by increasing lipid delivery to the liver in animal models as a common method, but particularly without the occurrence of hepatocyte injury and liver inflammation in most strains of mice (34). However, HFD feeding can induce NASH in C57BL/6J mice with many pathophysiological features of human NASH (14). Interestingly, fructose consumption promotes the progression of NASH in mice, since high-fat high-carbohydrate (HFHC) diet could induce increased hepatic inflammation during the process of NASH (15). High cholesterol diet (HCD, 4\% fat and $1 \%$ cholesterol) alone can only induced simple hepatic steatosis, with little inflammation. Dietary fat and cholesterol showed synergistic interaction in inducing NASH, as evidenced by the observation that high fat, high cholesterol diet (HFHC; $15 \%$ fat and $1 \%$ cholesterol) led to significant hepatic steatosis, liver inflammation and fibrosis (16). Mice fed by the FFC diet, a combination of high fat, fructose and cholesterol diet, recapitulated the features of human NASH better (17). A western diet (WD) mimicking fast food style diets, with high fatfructose-cholesterol, was used to induce NASH with obesity and insulin resistance, but the NASH progression is not accompanied by severe steatohepatitis and fibrosis even the mice were fed for a long-term more than 24 weeks (18). A Western diet with liquid fructose (WDF) feeding mice showed significant steatohepatitis and fibrosis (22). HFDs induce the reductions in some types of gut microbiota including Bacteroidetes, Lactobacilli and Bifidobacteria, and the increase in Firmicutes, thus contributing to the progression of NAFLD partially through dysbiosis (36).

Additionally, choline as an essential nutrient for humans, participates in several metabolism pathways, which influence obesity and insulin resistance $(37,38)$. Overweight/obese subjects showed abnormal choline metabolism, and human subjects with NASH exhibited lower hepatic phosphatidylcholinetophosphatidylethanolamine ratios compared to the healthy control (37). In the liver, choline is necessary to package and export TGs in VLDL and solubilize bile salts for secretion (37). Additionally, choline is required for intestinal bacterial metabolism, and in turn affects the composition of gut microbiome $(38,39)$. Humans fed with low-choline diets developed fatty liver and liver damage (40). Choline-deficient diet (CDD) and methionine-choline deficient (MCD) diet are used to generate NASH in mice (41). The choline-deficient L-amino aciddefined (CDAA) diet induces the same effects of the CDD (42). However, mice fed MCD diet or CD diet lose their body weight, without insulin resistance, although their liver tissues exhibit histological features of NASH (43). Thus, the combination of CD with HFD (CD+HFD) or MCD with HFD (HFMCD) has been used to induce NASH in mice with inhibition of weight loss $(21,22)$. 
TABLE 1 | Characteristics for each murine model of NASH.

\begin{tabular}{|c|c|c|c|}
\hline NASH models & Inducer & Pathological characteristics & References \\
\hline \multicolumn{4}{|c|}{ Diet-induced NASH } \\
\hline HFD & $\begin{array}{l}\text { Tailor-made milk fat, anhydrous milk fat }(21 \% \mathrm{w} / \mathrm{w}) \text { and sucrose } \\
(34 \% \mathrm{w} / \mathrm{w})\end{array}$ & $\begin{array}{l}\text { Obesity, insulin resistance } \\
\text { Macrovesicular steatosis, hepatocellular ballooning } \\
\text { Lobular inflammation, fibrosis (for } 20 \text { weeks) }\end{array}$ & (14) \\
\hline $\mathrm{HFHC}$ & $\begin{array}{l}58 \% \text { fat diet } \\
\text { Drinking water with } 42 \mathrm{~g} / \mathrm{L} \text { of carbohydrates ( } 55 \% \text { Fructose and } \\
45 \% \text { Sucrose by weight) }\end{array}$ & $\begin{array}{l}\text { Significantly obese, insulin resistant } \\
\text { Micro and macrovesicular steatosis } \\
\text { Lobular inflammation, hepatocyte apoptosis } \\
\text { Significant fibrosis (for } 16 \text { weeks) }\end{array}$ & (15) \\
\hline $\mathrm{HFHC}^{*}$ & $15 \%$ fat and $1 \%$ cholesterol & $\begin{array}{l}\text { Hypercholesterolemia and obesity } \\
\text { Hepatic steatosis, substantial inflammation, perisinusoidal } \\
\text { fibrosis, adipose tissue inflammation } \\
\text { Reduced plasma adiponectin levels (for } 30 \text { weeks) }\end{array}$ & (16) \\
\hline FFC & $40 \%$ fat, $42 \mathrm{~g} / \mathrm{L}$ fructose, and $0.2 \%$ cholesterol & $\begin{array}{l}\text { Insulin resistance, steatosis, inflammation hepatocellular } \\
\text { ballooning, progressive fibrosis (for } 25 \text { weeks) }\end{array}$ & $(17)$ \\
\hline $\mathrm{CD}+\mathrm{HFD}$ & Choline-deficient, $45 \%$ fat & $\begin{array}{l}\text { Hepatic steatosis, NASH (6 months old) } \\
\text { HCC ( } 25 \%) \text { (12 months old) }\end{array}$ & (21) \\
\hline HFMCD & Methionine and choline deficient diet supplemented with $60 \%$ fat & $\begin{array}{l}\text { Not obese or insulin resistant } \\
\text { Early-onset steatotic hepatitis, fibrosis (for } 10 \text { weeks) }\end{array}$ & (22) \\
\hline \multicolumn{4}{|c|}{ Chemical-induced NASH } \\
\hline $\mathrm{CCL}_{4} \mathrm{ND}$ & $\begin{array}{l}21.1 \% \text { fat, } 41 \% \text { sucrose, and } 1.25 \% \text { cholesterol and a high sugar } \\
\text { solution }(23.1 \mathrm{~g} / \mathrm{L} \text { d-fructose and } 18.9 \mathrm{~g} / \mathrm{L} \text { d-glucose }) \\
\mathrm{CCl}_{4}: 0.2 \mu \mathrm{L}(0.32 \mu \mathrm{g}) / \mathrm{g} \text { body weight }\end{array}$ & $\begin{array}{l}\text { Attenuated insulin resistance } \\
\text { Rapid progression of steatohepatitis } \\
\text { Fibrosis (for } 12 \text { weeks) } \\
\text { HCC (100\%) (for } 24 \text { weeks) }\end{array}$ & (23) \\
\hline $\mathrm{ob} / \mathrm{ob}$ or $\mathrm{db} / \mathrm{db}$ & HFD or MCD; high-calorie diet or supplemented with iron & $\begin{array}{l}\text { Insulin resistance } \\
\text { Fatty liver, steatohepatitis (for 1-3 months) }\end{array}$ & $(27,28)$ \\
\hline $\mathrm{GNMT}^{-/-}$ & Spontaneously & $\begin{array}{l}\text { Steatosis, steatohepatitis ( } 3 \text { months old) } \\
\text { Cirrhosis and HCC ( } 8 \text { months old) }\end{array}$ & (29) \\
\hline MC4R-KO & A high-fat diet & $\begin{array}{l}\text { Obesity, insulin resistance, dyslipidemia (for } 8 \text { weeks) } \\
\text { Steatohepatitis, inflammatory cell infiltration } \\
\text { Hepatocyte ballooning, pericellular fibrosis } \\
\text { Enhanced adipose tissue inflammation (for } 20 \text { weeks) } \\
\text { Well-differentiated HCC (100\%) (for } 1 \text { year) }\end{array}$ & (30) \\
\hline ALR-L-KO & $\begin{array}{l}\text { Liver-specific deletion of ALR } \\
\text { Spontaneously }\end{array}$ & $\begin{array}{l}\text { Steatosis, focal hepatocyte necrosis ( } 2-4 \text { weeks old) } \\
\text { Prominent bile ductular proliferation } \\
\text { Portal/periportal and lobular mixed inflammation ( } 4-8 \text { weeks } \\
\text { old) } \\
\text { HCC (nearly } 60 \% \text { ) (1 year old) }\end{array}$ & (31) \\
\hline $\operatorname{Ldllr}^{-/-}$ & $\begin{array}{l}\text { A high-fat-high-cholesterol diet (HFC) containing } 21 \% \text { milk butter, } \\
0.2 \% \text { cholesterol, } 46 \% \text { carbohydrates and } 17 \% \text { casein }\end{array}$ & $\begin{array}{l}\text { Steatosis, hepatic inflammation } \\
\text { Increased fibrosis and apoptosis (for } 3 \text { months) }\end{array}$ & (32) \\
\hline
\end{tabular}


TABLE 1 | Continued

\begin{tabular}{|c|c|c|c|}
\hline NASH models & Inducer & Pathological characteristics & References \\
\hline APOE2KI & $\begin{array}{l}\text { A western diet (17\% casein, } 0.3 \% \text { DL-methionine, } 34 \% \text { sucrose, } \\
14.5 \% \text { cornstarch, } 0.2 \% \text { cholesterol, } 5 \% \text { cellulose, } 7 \% \text { CM 205B, } \\
1 \% \text { vit } 200,21 \% \text { butter) }\end{array}$ & $\begin{array}{l}\text { Inflammation (for } 2 \text { days) } \\
\text { Steatosis, fibrosis } \\
\text { Impaired VLDL secretion (for } 4-7 \text { days) }\end{array}$ & (33) \\
\hline MUP-UPA & HFD (60\% of calories are fat derived) starting at 6 weeks of age & $\begin{array}{l}\text { Ballooning hepatocytes } \\
\text { Extensive numerous immune infiltration } \\
\text { Pericellular and bridging fibrosis (for } 24 \text { weeks) } \\
\text { HCC (30\%), adenomas (70\%) ( } 40 \text { weeks old) }\end{array}$ & (34) \\
\hline
\end{tabular}

HFD, high fat diet; HFHC, high-fat high-carbohydrate; HFHC*, high fat, high cholesterol diet; FFC, high-fat, high-fructose and high-cholesterol diet; WD, western diet; MCD, methioninecholine deficient diet; CD-HFD, choline-deficient high-fat diet; HFMCD, high-fat methionine- and choline-deficient diet; STAM, a NASH-derived hepatocellular carcinoma (HCC) model; PTEN, phosphatase and tensin homolog; ob/ob, leptin deficient; db/db, leptin receptor deficient; GNMT, glycine N-methyltransferase; MC4R, melanocortin 4 receptor; ALR, augmenter of liver regeneration; LDL, Ldlr, low density lipoprotein receptor; APOE2KI, APOE2 knock-in; UPA, urokinase plasminogen activator.

\section{Chemical-Induced NASH}

Streptozotocin (STZ) is used to induce type 1 diabetes with the toxicity to pancreatic $\beta$ cells. When mice administered with STZ were fed with HFD, they developed NASH with oxidative stress $(24,44)$. In the STAM model, low-dose STZ $(200 \mu \mathrm{g})$ is administered to neonatal mice via a single subcutaneous injection immediately after birth, followed by feeding HFD (32\% fat) at 4 weeks of age (25). Carbon tetrachloride $\left(\mathrm{CCl}_{4}\right)$ can serve as an accelerator in inducing NASH through significantly promoting the activation of HSCs and up-regulating ductular reaction and hepatocyte proliferation (23). The combined use of $\mathrm{CCL}_{4}$ and WD led to a rapid progression of steatohepatitis, closely replicating the features of human NASH (23). A combination of chronic treatment with $\mathrm{CCl}_{4}$ and $\mathrm{CDAA}$ diet was also used to induce NASH with fibrosis and HCC (45).

\section{Genetic-Induced NASH}

Leptin deficient mice (ob/ob) exhibit the accumulation of fat in the liver and severe insulin resistance, but rarely develop NASH. Additional stimulus such as HFD or MCD feeding has been shown to induce NASH development in ob/ob mice; however, the $\mathrm{ob} / \mathrm{ob}$ mice model is of some limitation for the study of NASH because the levels of leptin are normal or elevated in NASH patients (27). Similarly, leptin receptor-deficient mice $(\mathrm{db} / \mathrm{db})$ also had fatty liver and insulin resistance, as well as the features of NASH when stimulated with high-calorie diet or supplemented with iron $(28,46)$.

Phosphatase and tensin homolog (Pten) is a tumor suppressor gene. Liver-specific Pten deficient mice develop NASH with hepatic steatosis, inflammation and progressive fibrosis, since Pten deficiency induced adipogenic and lipogenic gene expression in hepatocytes and altered glucose metabolism and insulin sensitivity, possibly associated with increased expression of transactivating factors peroxisome proliferator-activated receptor $\gamma(\operatorname{PPAR} \gamma)$ and SREBP1c $(26,47)$. Glycine N-methyltransferase (GNMT) is the most important methyltransferase of the liver, which catabolizes Sadenosylmethionine (SAMe). GNMT-deficient mice developed spontaneous steatosis and progressed to NASH by spontaneously activating NK cells in the liver $(29,48)$. Melanocortin 4 receptor (MC4R) as a G protein-coupled receptor that expressed in the hypothalamic nuclei, regulates the food intake and body weight. MC4R-KO mice showed obesity, insulin resistance and dyslipidemia, and when fed HFD they developed steatohepatitis with infiltration of inflammatory cells, hepatocyte ballooning and liver peri-cellular fibrosis, similar to human NASH. Welldifferentiated HCC was observed in the MC4R-KO mice with the incidence rate of $100 \%$ after a HFD feeding for 1 year (30). Augmenter of liver regeneration (ALR) as a hepatic growth factor, is critical for mitochondrial function, hepatocyte survival and lipid homeostasis. Mice with liver-specific deletion of ALR had excessive steatosis and hepatocyte apoptosis, and nearly $60 \%$ of these mice progressed to $\operatorname{HCC}(31,49)$. Additionally, LDL receptor knock-out mice fed with a high-fat-high-cholesterol (HFC) diet showed steatosis, inflammation and increased apoptosis and hepatic fibrosis as a consequence of the increased sensitivity for oxidized LDL-induced inflammation, representing a highly suitable physiological model to study the onset of inflammation in NASH (32). APOE2 knock-in mice fed a western-type HFD developed NASH featured by steatosis and inflammation, due to impaired VLDL secretion and increased FFA synthesis and esterification or uptake (33). MUP-uPA mice with high amounts of urokinase plasminogen activator (uPA) specifically expressed in hepatocytes displayed classical features of human NASH and spontaneously progressed to HCC with additional treatment of HFD, in which hepatocyte ER stress was induced and consequently promoted the TNF production by inflammatory macrophages (34).

\section{INNATE AND INNATE-LIKE LYMPHOCYTES IN NASH DEVELOPMENT AND PROGNOSIS}

In the liver, innate and innate-like lymphocytes account for more than two-thirds of total lymphocytes and play a critical role in maintaining immune homeostasis. As a heterogeneous family, innate lymphoid cells (ILCs) are classified into groups 1,2 , and 3 , including five cell populations, namely NK, ILC1 (group 1), ILC2 (group 2), ILC3 and lymphoid tissue-inducer (LTi) cells (group 3) (50-53). It has been described that NK cells are generated from NK cell precursors (NKPs); ILC1s, ILC2s, and ILC3s are generated from ILCPs $\left(\mathrm{Lin}^{-} \mathrm{CD} 7^{+} \mathrm{CD} 127^{+} \mathrm{CD} 117^{+}\right.$ IL-1R1 $\left.{ }^{+} \mathrm{CD} 4 \mathrm{RA}^{+}\right)$; LTi cells are generated from lymphoid 
tissue-inducer progenitors (LTiPs). Common innate lymphoid progenitors (CILPs) are responsible for the generation of NKPs and common helper innate lymphoid progenitor cells (CHILPs); and then CHILPs give rise to LTiPs and ILCPs (50, 54-56). ILC1s are tissue-resident cells with the expression of CD49a and CD69; therefore, liver-resident NK (LrNK) cells with CD49a positive were particularly difficult to be discriminated from them, making the one cell population with two titles $(57,58)$. Several types of innate-like $\mathrm{T}$ cells enriched in the liver include invariant NKT, MAIT, and $\gamma \delta \mathrm{T}$ cells. The roles of these innate and innate-like lymphocytes, including NK cells/ILC1s, other ILCs, NKT, $\gamma \delta \mathrm{T}$, and MAIT cells were elucidated in the development of NASH (Figure 1).

\section{Natural Killer Cells (NK) and ILC1s}

In the liver, a large population of bulk NK cells represent $\sim 30-50 \%$ of total lymphocytes in humans and $10 \%$ of total lymphocytes in mice (59). Two distinct subsets are termed as liver-resident NK (LrNK)/liver-resident ILC1s and conventional
NK (cNK) cells with respect to their different origin, phenotype and function in the liver $(60,61)$. As described above, ILC1s develop from CHILPs that give rise to all members of ILCs but not NK cells; while NK cells develop form NKPs. Murine LrNK/ILC1s are characterized by a $\mathrm{Lin}^{-} \mathrm{CD} 45^{+}$ $\mathrm{NK} 1.1^{+} \mathrm{NKp}^{+} 6^{+} \mathrm{CD} 49 \mathrm{a}^{+} \mathrm{CD} 49 \mathrm{~b}^{-}$phenotype independent on Eomes, but require the transcript factors T-bet, Hobbit, PLZF and AhR for their development; while NK cells are $\mathrm{Lin}^{-} \mathrm{CD}^{+} 5^{+} \mathrm{NK} 1.1^{+} \mathrm{NKp} 46^{+} \mathrm{CD} 49 \mathrm{a}^{-} \mathrm{CD} 49 \mathrm{~b}^{+}$and strictly require Eomes for their development (57). Recent studies have determined the respective contribution of these two NK subsets in NASH.

TRAIL-producing NK cells actively promoted the hepatic inflammation with strong cytotoxicity at the early stages of fatty liver disease in the absence of GNMT, suggesting they may contribute to the progression of NASH in the $\mathrm{GNMT}^{-/-}$ mice which spontaneously develop steatosis and progress to steatohepatitis, cirrhosis and HCC (48). However, increased number of $\mathrm{CD}_{49 \mathrm{~b}^{+}} \mathrm{NKp} 46^{+} \mathrm{cNK}$ cells were demonstrated

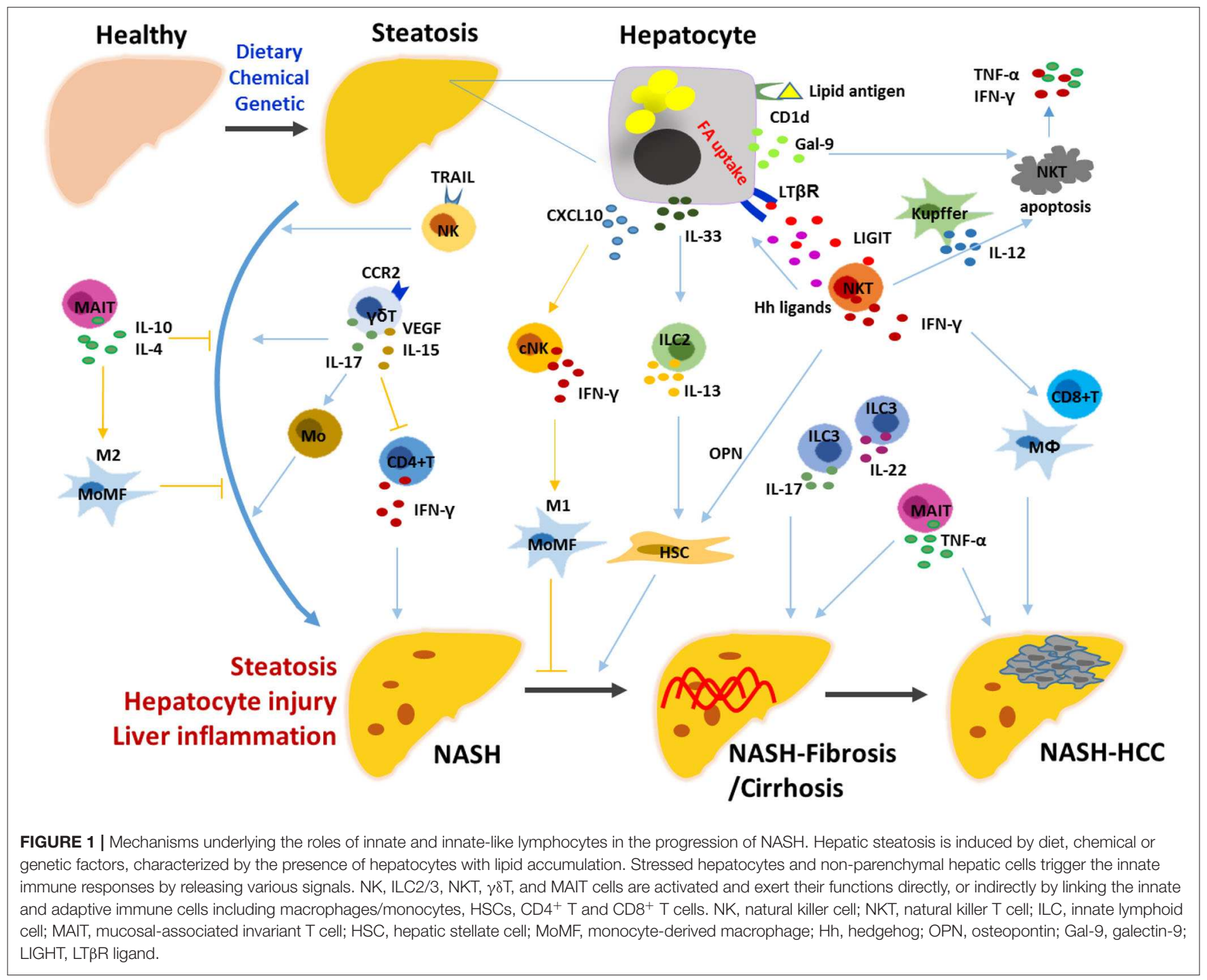


to prevent MCD-induced NASH progression to fibrosis by polarizing macrophage toward M1-like phenotypes, which depended on their production of IFN- $\gamma$ but not granzymemediated cytotoxicity (62). Increased expression of CXCL10 early after MCD treatment accounted for the recruitment of cNK cells into the liver, resulting in the attenuated inflammatory infiltration of $\mathrm{CD} 45^{+} \mathrm{CD} 11 \mathrm{~b}^{\text {hi }} \mathrm{F} 4 / 80^{\text {int }}$ monocytederived macrophages (MoMFs) particularly Ly6C ${ }^{\text {lo }}$ subsets skewed toward M2 (63). The upregulation of expression levels of chemokines including CXCL10, CCL2 and CCL5 was demonstrated to be dependent on IL-15 signaling in response to HFD in hepatocytes, which accounted for the recruitment of immune cells (64). IL-15 deficiency mice showed attenuated NASH with significantly decreased number of NK cells in the liver (64). Additionally, given that leptin plays an important role in NK cell development and activation, the attenuated NK cells may contribute to the development of NASH in $\mathrm{db} / \mathrm{db}$ mice with leptin receptor deficiency $(28,65)$.

LrNK/liver ILC1s are T-bet ${ }^{+}$Eomes $^{-} \mathrm{CD} 4 \mathrm{~b}^{-} \mathrm{CD}^{-} \mathrm{a}^{+}$ TRAIL $^{+}$with the potent ability to produce cytokines such as IFN- $\gamma$, TNF- $\alpha$, IL-2, and GM-CSF in mice $(56,66)$. During the progression of MCD-induced NASH, the loss of CD49a ${ }^{+}$NK1.1 $1^{+}$ ILC1s was found to be induced in the liver, and the function of $\mathrm{CD} 49 \mathrm{a}^{+} \mathrm{NK} 1.1^{+}$ILC1s could not be precisely determined (62). Noticeably, ILC1s were enriched for the expression of inhibitory receptor CD200r1; while little to no expression of CD200r1 was observed on peripheral NK cells, and CD200r1 was stable to identify ILC1s during MCMV-induced inflammation, suggesting that CD200r1 will be a more useful marker to accurately track the ILC1s during inflammation (67). Adiposeresident ILC1s/trNK-derived IFN- $\gamma$ triggered pro-inflammatory macrophage polarization and promoted insulin resistance in response to adipocyte stress induced by a high-fat diet (68, 69). At steady state, enriched adipose type 1 ILCs including circulating mature NK cells, tissue-resident iNK and CD49a ${ }^{+}$ mixed ILC1 subsets, killed adipose tissue macrophages (ATMs) to regulate ATM homeostasis, but the killing ability was impaired in obesity, contributing to the skewing toward pro-inflammatory macrophages and their accumulation in adipose (70). The conversion of effector NK cells $\left(\mathrm{CD} 49 \mathrm{a}^{-} \mathrm{CD} 49 \mathrm{~b}^{+}\right.$Eomes $\left.^{+}\right)$was demonstrated into ILC1s including intermediate ILC1 (intILC1) $\left(\mathrm{CD} 49 \mathrm{a}^{+} \mathrm{CD}_{4} 9 \mathrm{~b}^{+}\right.$Eomes $\left.^{+}\right)$and ILC1 $\left(\mathrm{CD} 49 \mathrm{a}^{+} \mathrm{CD} 49 \mathrm{~b}^{-}\right.$ Eomes $^{\text {int }}$ ) populations that were not capable of restraining tumor growth and metastasis through TGF- $\beta$ signaling in the tumor microenvironment (71). Whether these adipose ILC1-like cells undergo NK cell or ILC1 conversion need further investigation. In the obese liver, the conversion of NK cells toward ILC1like cells with increased expressions of CD200r1 and CD49a was observed, partially mediated by the higher expression of TGF- $\beta$ (72). The reduction in NK cell cytotoxicity due to the shift toward ILC1 characteristics showed protective roles in the progression of NASH (72). Additionally, lipids not only accumulate in hepatocytes but also in immune cells, suggesting metabolic reprogramming of NK cells may be involved in the pathogenesis of NASH. Obesity induced robust PPARdriven lipid accumulation in NK cells, leading to impaired
mTOR signaling and complete "paralysis" of their cellular metabolism and effector molecule expression, as demonstrated by the blunted anti-tumor responses (73). Involvement of liver-resident ILC1s in the development of NASH may be related to the inducing factors and pathological features of the disease.

In human NASH patients, hepatic CXCL9, CXCL10, CXCL11, CCL3, CCL4, and CCL5 levels were markedly higher than that of the healthy controls and the level of circulating CXCL10 was correlated with the severity of lobular inflammation $(74,75)$. These chemokines have the chemotactic activity of NK cells; however, the frequency of hepatic NK cells remained unaffected by clinical stage of NASH. The frequency and number of peripheral NK cells also remained unaltered in NASH patients. Only the phenotype of both CD56 ${ }^{\text {bright }}$ and CD56 $6^{\text {dim }}$ NK cells in the peripheral blood showed an alteration with much higher levels of NKG2D expressed on their surface (76). Notably, the number of hepatic NK cells was significantly increased in NASH patients with obesity compared with that in the healthy controls, along with higher expression levels of NKG2D and $\mathrm{MICA} / \mathrm{B}$ in the liver, suggesting that NK cells may contribute to the progression of NASH through MICA/B (77). However, during obesity the number of peripheral NK cells increased and they were activated with elevated expressions of CD69 and Granzyme B, but had an impaired ability to respond and eliminate target tumor cells, which was highly related to the severity of obesity (78). The tissue-specific microenvironment is important to shape the local NK cell population, as shown by the significant differences in the composition of NK cells independently of disease status among liver, adipose tissue and peripheral blood. Studying the tissue-resident cell population is important to understand the pathogenesis of NASH (76).

In the human liver, unique resident NK cells were identified as CD49a ${ }^{+} \mathrm{CD}_{6} 6^{\text {bright }} \mathrm{NK}$ cells, CXCR6 ${ }^{+} \mathrm{NK}$ cells or CD $49 \mathrm{e}^{-}$ NK cells according to their some similarity to murine LrNK cells, respectively, (79-81). However, the presence of CD49a ${ }^{+}$ CD56 ${ }^{\text {bright }} \mathrm{NK}$ cells is unstable with a significant variation in the frequency in the human liver $(79,82)$. Recent studies showed that the ability of intrahepatic NK cells defined as $\mathrm{CD}_{4} 5^{+} \mathrm{CD}^{-}$ CD56 ${ }^{+}$T-bet ${ }^{\text {hi }}$ Eomes ${ }^{\text {lo }}$ to degranulate and their killing activity was inversely correlated with the severity of NAFLD/NASH, and also the liver-resident $\mathrm{NK}$ cells defined as $\mathrm{CD} 45^{+} \mathrm{CD}^{-} \mathrm{CD} 56^{+}$ T-bet ${ }^{\text {lo }}$ Eomes ${ }^{\text {hi }}$ exhibited decreased ability to degranulate (72). Given that the identification of human LrNK cells remains challenge, the roles of LrNK cells in the development of NASH are still unclear.

\section{Other Innate Lymphoid Cells: ILC2s and ILC3s}

ILC2s are mostly localized in the barrier tissues such as gut, lung, skin and also liver, which express Gata-3 and ROR $\alpha$ and secrete cytokines IL-5 and IL-13 (83). ILC3s are mostly concentrated in the gut, which express ROR $\gamma$ t to drive the production of cytokines IL-17A and/or IL-22 $(56,84)$. The $\mathrm{CD}_{4} 5^{+} \mathrm{Lin}^{-}$ $\mathrm{CD}_{12}{ }^{+} \mathrm{CD}_{16}{ }^{-} \mathrm{NKG}_{2} \mathrm{~A}^{-} \mathrm{CD} 161^{+}$ILC population in the human liver can be subgrouped into four distinct populations: 
CD117 ${ }^{-} \mathrm{NKp}_{4} 4^{-} \mathrm{CRTH}_{2}{ }^{-}$ILC1, CRTH2 ${ }^{+}$ILC2, and CRTH2 ${ }^{-}$ CD117 ${ }^{+} \mathrm{NKp}_{4} 4^{-}$ILC3 and CRTH2 ${ }^{-} \mathrm{CD} 117^{+} \mathrm{NKp} 44^{+}$ILC3 cells, with a composition and phenotype significantly different dependent on age (85). In the adult liver, NKp44- ILC3s accounted for the major population of total ILCs, while ILC2s represented a small population of ILCs (85). During the different steps of NAFLD/NASH development, poor studies evaluated the contribution of ILC2 and ILC3 subsets.

The frequency of ILC2s in the fibrotic liver was increased, which was correlated with the degree of fibrosis for patients; however, their phenotypes were similar to the ILC2s in nonfibrotic livers, with high expression level of CD69 and low expression level of CD62L, which were markedly distinct from the ILC2s in peripheral blood (85). The results indicated that the increased number of ILC2s in the fibrotic liver was not due to the recruitment of ILC2s from the peripheral blood, indicating the possible mechanisms in humans similar to the previous findings in mice. In a murine model of chemicalinduced liver fibrosis, the expression of IL-33 was evaluated due to the chronic hepatocellular stress, and then IL-33 mediated the accumulation and activation of ILC2s through ST2-dependent signaling. Activated hepatic ILC2s produced IL-13, which in turn promoted hepatic fibrosis through triggering HSC activation (86). Additionally, IL-33 also could directly activate HSCs to drive hepatic fibrosis (87). In the human livers, IL-33 and thymic stromal lymphopoietin (TSLP) also promoted ILC2s to produce potentially profibrotic cytokine IL-13 (85). Adipose-resident ILC2s produced methionine-enkephalin peptides to regulate adipose function and metabolic homeostasis via promoting beige fat formation; and ILC2s-derived type 2 cytokines also played a critical role in the regulation of adipocyte precursor numbers and fate via the IL- $4 \mathrm{R} \alpha$ in PDGFR $\alpha+$ adipocyte precursors (APs) to promote beige fat biogenesis $(88,89)$. However, ILC2 populations were dysregulated in white adipose tissue (WAT), as a conserved feature of obesity in mice and humans (88).

In human livers with fibrosis, the frequency of NKp44ILC3 was markedly decreased in accordance with the degree of disease. It was speculated that NKp44- ILC3s in fibrotic livers plastically changed into ILC2s since the overall frequency of ILCs remained unaltered in fibrotic livers compared with that in the livers of healthy individuals (85). In a $\mathrm{CCl}_{4}$-induced mouse liver fibrosis model, larger numbers of IL-17A ${ }^{+}$ILC3 and IL-22 $2^{+}$ILC3 subsets were presented in the liver and the pro-fibrotic effects of ILC3s were determined (90). However, localized IL-22 in the liver derived from T cells or some other undetermined cells was demonstrated as a survival factor for hepatocytes, preventing and repairing liver injury, accelerating liver regeneration, but promoting the susceptibility to tumor development (91-93). In obese mice, induction of IL-22 from ILCs was significantly impaired. Administration of IL-22 could reverse many of the metabolic symptoms via improving insulin sensitivity, preserving gut mucosal barrier, dampening chronic inflammation and regulating lipid metabolism in liver and adipose tissue (94).

\section{Natural Killer T Cells (NKT)}

NKT cells are the major population of innate-like lymphocytes in the liver, which express both surface markers on NK cells (such as NK1.1 in mice and CD56 in humans) and semi-invariant (V $\alpha 14 / \mathrm{J} \alpha 18 / \mathrm{TCR} \beta$ chains, including $\mathrm{V} \beta 8.2, \mathrm{~V} \beta 7$ and $\mathrm{V} \beta 2$ in mice; $\mathrm{V} \alpha 24 / \mathrm{J} \alpha 18 / \mathrm{V} \beta 11$ in humans) or diverse TCRs, and are divided into two main subsets: invariant NKT (iNKT) and noninvariant NKT cells. iNKT cells are particularly enriched in the liver as liver-resident populations in mice and humans, which can recognize lipid antigens by CD1d (95). Their roles in the progression of NASH remain controversial.

iNKT cells were demonstrated to play a protective role against liver inflammation and liver injury progressing to fibrosis during the HFD-induced NASH, but not against lipid accumulation/steatosis (96, 97). In mice fed with a high fat or sucrose diet, increased apoptosis of NKT cells was induced in the liver, which resulted in the reduced NKT cells and promoted hepatic inflammation by excessive production of IFN- $\gamma$ and TNF- $\alpha$ (98). The loss of NKT cells was dependent on KCs and IL-12 in hepatosteatosis (99). Additionally, the Gal-9/Tim-3 interaction induced Tim- $3^{+}$NKT cell apoptosis, which contributed to the depletion of NKT cells in the liver with HFD-induced steatosis (100). However, in Tim-3 knockout (KO) mice MCD-induced liver steatosis was significantly accelerated, which was demonstrated to be related to the activation of macrophages but not NKT cells (101). Notably, roles of NKT cells was oppositely determined by distinct populations of macrophages, since NKT cells activated by M2 macrophages inhibited mataflammation and insulin resistance by promoting Th2 responses in visceral adipose tissues (VATs) of obesity, while NKT cells activated by M1 macrophages exacerbated mataflammation and insulin resistance by promoting Th1 responses (102).

During MCD-induced NASH, NKT cells were accumulated via Hedgehog $(\mathrm{Hh})$ pathway activation or IL-15 stimulation, and subsequently NKT cells promoted HSC activation to become myofibroblasts (MF) through production of osteopontin (OPN) and hedgehog $(\mathrm{Hh})$ ligands (103-105). The hepatic recruitment and adhesion of NKT cells was related to the Hh-dependent production of CXCL16 and expression of VCAM-1 by immature ductular cells (103). In CD1d ${ }^{-/-}$mice which lack NKT cells, the progressive liver fibrosis induced by MCD was prevented (103). In CDAA-induced and HFHC-induced murine NASH model, the presence of iNKT cells was also necessary for the steatosis, steatohepatitis and fibrosis (106, 107). Differential activation of iNKT cells skewed from predominantly NKT17 $\left(\mathrm{IL}-17^{+}\right.$iNKT and IL-22 ${ }^{+}$iNKT) to NKT1/NKT2 $\left(\mathrm{IFN} \gamma^{+}\right.$ iNKT, IL- $4^{+}$iNKT and IL-13 ${ }^{+}$iNKT) played a pathogenic role in mediating the progression from steatosis to fibrosis by promoting the infiltration of $\mathrm{CD}^{+} \mathrm{T}$ cells and macrophages and the activation of HSCs (106). Further, by using a CDHFD-induced NASH-driven HCC model, it was demonstrated that NKT cells primarily initiated steatosis via secreted LT $\beta$ R ligand (LIGHT)-promoted hepatocyte FA uptake, and induced 
liver damage and HCC development cooperatively with $\mathrm{CD}^{+}$ $\mathrm{T}$ cells (21).

In humans, the number of intrahepatic NKT cells was found to be significantly increased in the patients with moderate to severe steatosis, NASH or NSAH-cirrhosis $(21,103,108)$. Notably, significantly enhanced expression level of LIGHT was found in the livers of NASH patients, and NKT cells were shown to be one of the major sources of LIGHT (21). In human NASH livers with advanced fibrosis, higher levels of OPN and Hh ligands were found compared with those with early fibrosis, and the levels were correlated with fibrosis severity, indicating the role of NKT cellsderived OPN in promoting fibrogenesis during NASH (105). The frequencies of peripheral CXCR $3^{+}$IFN- $\gamma^{+}$T-bet ${ }^{+}$and IL-17A ${ }^{+}$ iNKT cells were also increased in NASH patients in comparison with those in non-alcoholic fatty liver (NAFL) patients or healthy controls (106).

\section{$\gamma \delta$ T Cells}

$\gamma \delta \mathrm{T}$ cells are a distinct subset of $\mathrm{CD}^{+}{ }^{+} \mathrm{T}$ cells that express $\gamma \delta$ TCRs. In the adult liver, $\gamma \delta \mathrm{T}$ cells represent a frequency of $3-5 \%$ of the total hepatic lymphocytes, which is $\sim 5-10$-fold greater than that in other tissues and organs (109). Hepatic $\gamma \delta \mathrm{T}$ cells are liver-resident cells that predominantly produce a high level of IL-17A, and their homeostasis is maintained by the gut microbiota in a lipid antigen/CD1d-dependent manner, including cell activation, survival and proliferation (110).

In HFD-fed or high-fat/high-carbohydrate diet (HFHCD)-fed mice, significantly elevated numbers of $\gamma \delta \mathrm{T} 17$ cells were present in the liver, which contributed to the steatohepatitis, liver damage, and glucose dysmetabolism through the production of IL-17A (110). Furthermore, the increase in hepatic $\gamma \delta$ T17 cells occurred only in the presence of gut microbiota during the progression of NASH (110). During HFD-induced obesity, adipose tissue-resident $\gamma \delta \mathrm{T}$ cells promoted inflammatory response by regulating macrophages, and increased systemic insulin resistance (111). In steatohepatitis, $\gamma \delta \mathrm{T}$ cells expanded and exhibited a distinctly activated phenotypes with decreased expression of $\mathrm{V} \gamma 1, \mathrm{CD} 27$ and $\mathrm{CD} 69$, and with increased expression of programmed cell death-1 (PD-1), CD1d and CD36 (112). The recruitment of $\gamma \delta \mathrm{T}$ cells, mainly IL-17 high $\mathrm{Ly}^{-} \mathrm{C}^{-}$ CD $44^{+} \gamma \delta \mathrm{T}$ cells was in a CCR2-dependent manner in the liver with steatohepatitis, which resulted in promoting the influx of inflammatory monocytes and mitigating IFN- $\gamma$ production in $\mathrm{CD}^{+} \mathrm{T}$ cells (112). The $\gamma \delta \mathrm{T}$ cell-derived cytokines VEGF and IL-15, but not IL-17A in a CD1d-dependent manner were demonstrated to play the key role in orchestrating the programming of the adaptive immune responses during the progression of NASH (112). During the progression of NASH, hepatic $\gamma \delta \mathrm{T}$ cells played pathogenic roles by connecting the innate and adaptive immune responses (113). In the healthy human liver, infiltrating $\gamma \delta \mathrm{T}$ cells $\left(\mathrm{CD} 27^{\mathrm{lo} /-} \mathrm{V} \delta 2^{-}\right)$comprise populations of both clonally expanded circulating and tissueresident $\gamma \delta \mathrm{T}$ cells, and liver-resident $\mathrm{V} \delta 1^{+} \gamma \delta \mathrm{T}$ cells $\left(\mathrm{CD} 45 \mathrm{RA}^{-}\right.$, $\mathrm{CD} 9^{+}, \mathrm{CXCR}^{+}, \mathrm{CXCR}^{+}, \mathrm{CD}_{103^{-}}, \mathrm{IFN}-\gamma^{+}, \mathrm{TNF}-\alpha^{+}$) are phenotypically and functionally distinct from circulating ${\mathrm{V} \delta 1^{+}}^{+} \delta \mathrm{T}$ cells $\left(\mathrm{CD} 45 \mathrm{RA}^{+}, \mathrm{CD}_{103}{ }^{-}, \mathrm{CX}_{3} \mathrm{CR} 1^{+}, \mathrm{Granzyme}^{+}\right.$, Perforin ${ }^{+}$) (114). A distinct population of $\mathrm{V} \delta 3^{+} \gamma \delta \mathrm{T}$ cells is enriched and may also be activated to produce IL-17A in CD1ddependent manner $(115,116)$. The pathogenic role of hepatic $\gamma \delta \mathrm{T}$ cells in NASH patients deserves further investigation.

\section{Mucosal-Associated Invariant T (MAIT) Cells}

MAIT cells, as an innate-like $\mathrm{T}$ cell population, are usually identified as $\mathrm{CD}^{+} \mathrm{CD}^{-} \mathrm{CD}^{-} 61^{+} \mathrm{V} \alpha 7.2^{+}$lymphocytes in humans and $\mathrm{CD}^{+} \mathrm{CD}^{-} \mathrm{CD}^{-} 61^{+} \mathrm{V} \alpha 19^{+}$lymphocytes in mice, with a limited repertoire of $\beta$ chain (predominantly $\mathrm{V} \beta 6$ and $\mathrm{V} \beta$ 20) $(117,118)$. MAIT cells recognize vitamin $B$ metabolites by the presentation with major histocompatibility complex (MHC) class I-like molecule MR1. MAIT cells, which are clearly enriched in human livers, constitute up to $20-50 \%$ of all intrahepatic $\mathrm{T}$ cells, and are predominantly located to bile ducts in the portal tracts $(117,119)$. MAIT cells display an effector and memory phenotype $\left(\mathrm{CD} 45 \mathrm{RA}^{-}, \mathrm{CD} 45 \mathrm{RO}^{+}, \mathrm{CD} 44^{\mathrm{hi}}, \mathrm{CD} 62 \mathrm{~L}^{\mathrm{lo}}, \mathrm{CD} 122^{\text {int }}, \mathrm{CD} 127^{\mathrm{hi}}\right.$, CD95 ${ }^{\text {hi }}$ ) and rapidly respond to antigen stimulation in a TCRdependent manner and to cytokine stimulation (such as IL-12, IL-18) in a TCR-independent manner, to produce cytokines TNF$\alpha$, IFN- $\gamma$, and IL-17 and cytotoxic molecules granzyme B and perforin $(117,119)$.

In patients with obesity, preferentially recruited MAIT cells were found in adipose tissue and displayed a strong production of IL-17, which resulted in a significantly reduced frequency in the peripheral blood (118). In patients with NASH-related cirrhosis, although the frequency of circulating MAIT cells was reduced, these cells exhibited an activated phenotype; furthermore, the frequency of hepatic MAIT cells was also decreased, but these cells accumulated in the mesenchymal space within the fibrotic septa (120). The profibrogenic functions of MAIT cells were demonstrated in $\mathrm{CCl}_{4}$-induced liver fibrosis by using MAIT cell-deficient mice and Va19 TCR Tg-mice with a 10-fold increase in the frequency of MAIT cells (120). MAIT cells were found to enhance fibrogenic functions of hepatic myofibroblasts by promoting their proliferation in an MR1-dependent manner and enhancing their proinflammatory properties through the production of TNF- $\alpha$ (120). However, in a MCD-induced NASH model, MAIT cells were enriched in the livers and found to be protective against liver inflammation through the production of IL-4 and IL10 and the induction of anti-inflammatory M2 macrophages (121). These controversial results indicated that the precise role of MAIT cells in the pathogenesis of NASH requires further clarification.

\section{METABOLIC REGULATION OF INNATE IMMUNE RESPONSES}

In steatotic hepatocytes, lipids are major stored in the form of triglycerides (TG), and as several other lipid metabolites such as FFA, diacylglycerol (DAG), free cholesterol (FC), cholesterol ester (CE), ceramide, and phospholipid (122). Excessive accumulated lipids in hepatocytes may enter nonoxidative deleterious pathways, leading to hepatocyte damage. Here, metabolic regulation is addressed in consideration 
to explain the molecular mechanisms by which lipid accumulation in hepatocytes drives the activation of innate immune cells and the inflammatory response (Figure 2). Some studies also indicated that metabolic changes in innate and innate-like lymphocytes associated with NASH progression.

\section{Lipotoxicity}

FFAs and other derived metabolites induce toxic effects known as lipotoxicity, which mediate the apoptosis, necrosis, necroptosis and pyroptosis of hepatocytes and then induce the inflammation in the liver (123-126). TG formation in hepatocytes plays a protective role by preventing FFA-induced damage to hepatocytes, since the inhibition of TG synthesis exacerbates liver damage and fibrosis although improves hepatic steatosis (127-129).

FFAs promoted hepatic lipotoxicity by stimulating TNF- $\alpha$ expression via the induction of lysosomal destabilization in a ctsb-dependent manner (130). FFAs sensitized hepatocytes with the high expression of TRAIL-receptor and the death receptor Fas (CD95) to the TRAIL-mediated and FasL-mediated apoptosis by immune cells (124). In humans, increased content of free cholesterol also sensitized hepatocytes to the apoptotic effects of TNF- $\alpha$ and Fas $(131,132)$. Saturated FAs as an endogenous danger molecule up-regulated the activation of inflammasome and also induced mitochondrial dysfunction to stimulate the production of reactive oxygen species (ROS) in hepatocytes, and furthermore FFAs and fragments as DAMPs derived from the damaged hepatocytes, activated and mobilized KCs, DCs and other innate lymphocytes by binding to TLR2, TLR4 and TLR9, resulting in the recruitment of neutrophils and lymphocytes and thus orchestrating the inflammatory response $(124,133)$. The elevated proinflammatory cytokines in the fatty livers including TNF- $\alpha$, IL-1 $\beta$, IL-18, IL-33, and MCP-1 activate and regulate NK cells, ILCs and other innate-like lymphocytes to participate in the pathogenesis. Additionally, in obesity lipid accumulation in NK cells via PPAR impaired their cellular metabolism and cytotoxicity (73).

FFAs also directly induced a hepatocyte endoplasmic reticular (ER) stress response, which led to failure of the unfolded protein response (UPR) and hepatocyte apoptosis (134-136). Inositol-requiring enzyme 1 alpha (IRE1 $\alpha)$, protein kinase RNA (PKR)-like endoplasmic reticulum kinase (PERK) and activating transcription factor 6 (ATF6) are the ER stress sensors for lipids, and B-cell lymphoma 2 (BCL2)-associated X protein

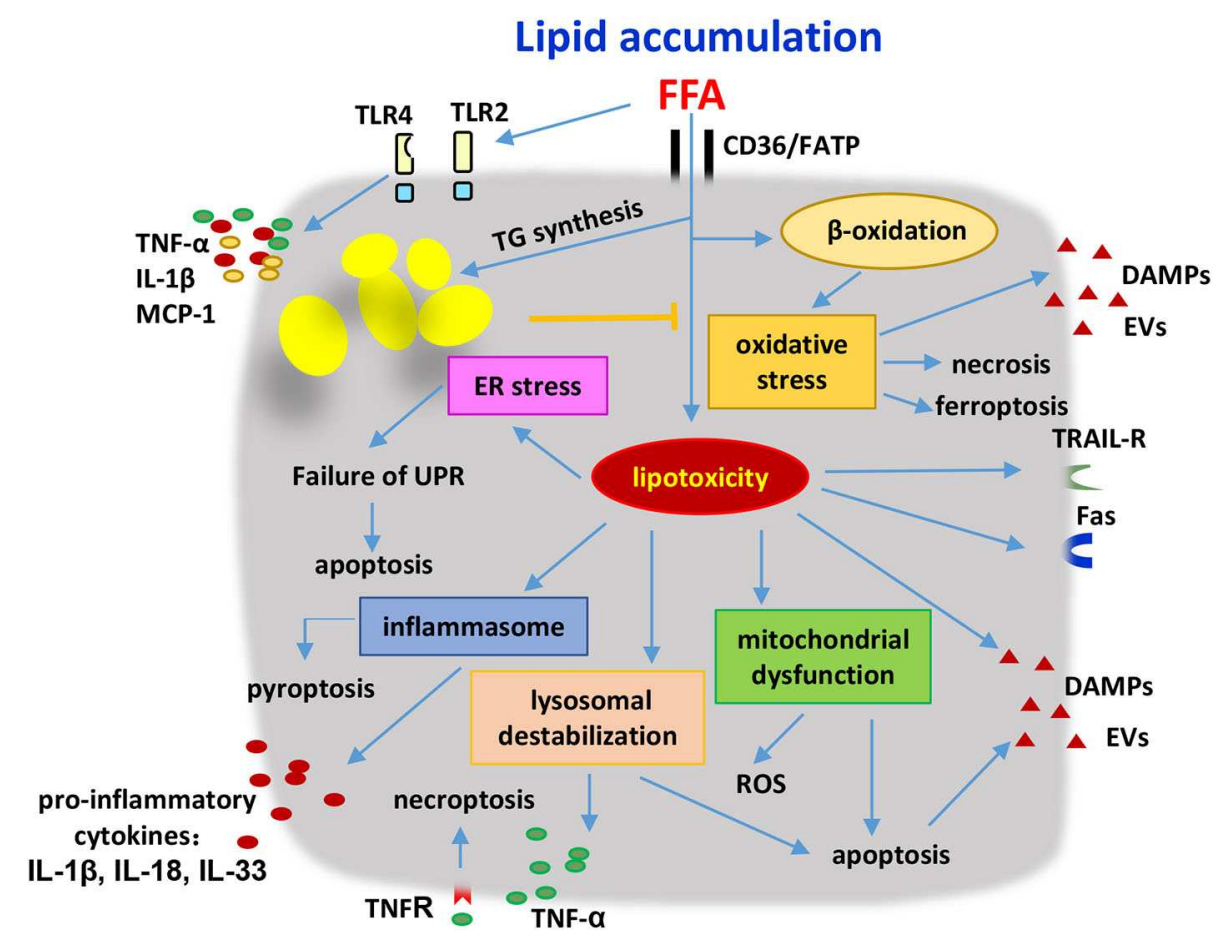

FIGURE 2 | Hepatocytes were stressed or damaged by lipid accumulation and produced pathogenic mediators to induce the innate immune responses. Hepatocytes were induced to undergo apoptosis, necrosis, necroptosis and pyroptosis as a result of the lipotoxicity and oxidation stress. Lysosome destabilization, mitochondrial dysfunction, ER stress, inflammasome activation, and TLR signaling were involved in the development of metabolic disorders. Stressed or damaged hepatocytes secreted several kinds of pro-inflammatory cytokines including TNF- $\alpha, \mathrm{LL}-1 \beta, \mathrm{IL}-18, \mathrm{IL}-33$, MCP-1, and produced DAMPs and EVs to activate the innate immune cells. Additionally, hepatocytes with lipid accumulation were sensitive to the cytotoxicity of immune cells due to the higher expression levels of death receptors on their surface. FFA, free fatty acids; FATP, fatty acid transport proteins; TG, triglycerides; ER, endoplasmic reticular; UPR, unfolded protein response; ROS, reactive oxygen species; DAMPs, damage-associated molecular patterns; EVs, extracellular vesicles; TRAlL-R, tumor necrosis factor-related apoptosis-inducing ligand receptor; TNF, tumor necrosis factor; IL, interleukin; MCP-1, monocyte chemoattractant protein 1. 
(Bax) inhibitor-1 (BI-1) is a negative regulator of the ER stress sensor. Reduced BI-1 led to the progression of NASH and type 2 diabetes, linked to the activation of NLRP3 inflammasome via up-regulating IRE1 $\alpha$ endoribonuclease (RNase) signaling (137). ER stress-driven NF- $\kappa \mathrm{B}$ activation promoted the secretion of inflammatory and chemotactic factors, involved in steatosis progression to NASH $(138,139)$. Additionally, ER stress decreased the expression of CD1d in hepatocytes, contributing to NKT cell dysregulation in fatty livers (140). However, ER stress in macrophages potently induced CD1d-dependent iNKT cell autoreactivity via IRE1 $\alpha /$ PERK pathways, since macrophages undergoing ER stress generated the neutral lipids that were enriched and loaded onto CD1d to activate iNKT cells (141). HFD-enhanced ER stress in adipocytes suppressed Th2 cytokine expression, which modulated adipose tissue macrophage polarization toward M1 and mediated systemic insulin resistance (142). In T2D patients, ER stress was activated in NK cells, leading to the defects in the expression of the activating receptors NKG2D and NKp46 (143). Regulation of ER stress on the activity and function of innate lymphocytes deserves further investigation during the progression of NASH.

Further, hepatocytes exposed to lipotoxic stress released several types of extracellular vesicles (EVs) as pathogenic mediators to activate immune cells and promote inflammation, including exosomes, microvesicles and apoptotic bodies (126). Thus, lipotoxicity along with the activation of innate immune cells is the major driver of NASH.

\section{Oxidative Stress}

In addition to the formation of TG, FFAs can be catabolized through mitochondrial or peroxisomal $\beta$-oxidation in hepatocytes, which consequently lead to the production of oxygen free radicals, hydrogen peroxide and other lipid peroxidation products $(144,145)$. In hepatocytes with lipid accumulation, oxidative stress induced the release of DAMPs and EVs, and the production of antigens, to initiate the innate immune response and trigger the adaptive immune responses, respectively (104). Promoted Th1 activation by oxidative stress-induced antigens induced NKT cell recruitment into the liver through selectively upregulated IL-15, which participated in the progression of NASH (104). Recently, it was found that alkaline ceramidase 3 (ACER3) mediated palmitic-acidinduced oxidative stress and played the pathological role in NASH. Targeting ACER3 could alleviate the severity of NASH by suppressing the hepatocellular oxidative stress, thus attenuating early inflammation and fibrosis but not steatosis, demonstrated by the similar area of steatosis and significantly reduced number of inflammatory foci, lower expression levels of IL- 6 , TNF- $\alpha$ and TGF- $\beta$, and minor fibrosis in Acer $3^{-/-}$ mice (146). Oxidized phospholipids (OxPLs) accumulated and induced oxidative stress and mitochondrial damage in NASH. Neutralization of OxPLs was effective to ameliorate NASH by decreasing the expression of a variety of inflammatory chemokines and cytokines such as Ccr2, Ccr5, Ccl6, Cx3cr1, Cxcl14, Il1a, reducing recruitment of monocyte-derived macrophages into the liver and promoting shift of $\operatorname{Tim} 4^{-}$to
Tim $4^{+}$macrophages that mediated engulfment of apoptotic cells (147). Ferroptosis induced by lipid peroxidation was considered to play a major role in the development of NASH with increased expressions of IL- $1 \beta$, IL- 6 , TNF- $\alpha$, TGF- $\beta$, and MCP-1 $(148,149)$.

\section{INTERVENTION STRATEGIES AGAINST NASH BASED ON INNATE AND INNATE-LIKE LYMPHOCYTES}

The effective prevention and control of NASH remains a clinical challenge. As described above, stressed/damaged hepatocytes with lipid accumulation trigger innate immune responses through several pathways; furthermore, hepatic NK, ILCs, NKT, $\gamma \delta \mathrm{T}$, and MAIT cells are involved in the pathogenesis of NASH. Based on these findings, the development of immunebased interventions to control the progression of NASH has been proposed.

Anti-inflammatory agents targeting TNF- $\alpha$ signaling, such as a pan-caspase inhibitor emricasan and a methylxanthine derivative pentoxifylline (PTX), were evaluated in clinical trials for NASH patients (150). However, emricasan treatment lowered serum ALT in the short-term but worsened liver fibrosis and hepatocyte ballooning due to alternative cell death in patients with NASH; and also no beneficial effect of emricasan was observed in NASH-related cirrhosis patients (151, 152). As described above, the contribution of NK cells and ILC1s was evaluated in the hepatocyte injury and liver inflammation during the progression of $\mathrm{NASH}$, suggesting a strategies against NASH through targeting NK and ILC1s, especially the metabolic regulation $(72,153)$. Strategies targeting the IL-33/ILC2/beiging pathway may represent a new therapeutic approach to treat obesity and obesity-associated diseases (88). The therapeutic modulation of IL-33-dependent networks has also been demonstrated in hepatic inflammation and fibrosis (86). Given the critical role of CD1d in the activation and regulation of $\gamma \delta \mathrm{T}$ cells, approaches involving the targeting of CD1d and $\gamma \delta \mathrm{T}$ cells may have therapeutic potential for the treatment of NASH (110). Treatment with the RAR- $\gamma$ agonist Tazarotene was found to significantly reduce steatosis and fibrosis by inhibiting the proliferation and cytokine secretion of iNKT cells (106). Dietary glycine has been shown to prevent the progression of NASH by ameliorating oxidative stress and inflammatory infiltration involving NKT cells as well as M2 transformation of KCs in the liver (154). Efficiently reducing the numbers of intrahepatic $\mathrm{CD}^{+} \mathrm{T}$ and/or NKT cells, as well as preventing their cross-talk with hepatocytes by targeting LIGIT-LT $\beta \mathrm{R}$ or the hedgehog pathway offers the potential to inhibit liver damage, NASH and HCC $(21,105)$.

\section{CONCLUSION}

Liver is an immunologic organ that contains a large number of innate immune cells. Using murine NASH models, innate and innate-like lymphocytes, including NK cells, ILCs, NKT, $\gamma \delta \mathrm{T}$, and 
MAIT cells have been demonstrated to play critical roles in the progression of NASH. Other innate immune cells such as KCs, neutrophils and DCs have been described in detail elsewhere. Disordered lipid metabolism in hepatocytes initiates the innate immune responses. Additionally, extra-hepatic factors such as dysfunctional adipose tissue and altered gut microbiota, as well as extra-hepatic cells have also been found to be involved in the development of NASH. Further studies in NASH patients are necessary to confirm these findings. Continuous efforts toward understanding of the complex immune mechanisms underlying NASH development should offer new avenues for the management and prevention of this disease.

\section{REFERENCES}

1. Younossi ZM, Koenig AB, Abdelatif D, Fazel Y, Henry L, Wymer M. Global epidemiology of nonalcoholic fatty liver disease-Meta-analytic assessment of prevalence, incidence, and outcomes. Hepatology. (2016) 64:73-84. doi: 10.1002/hep.28431

2. Suzuki A, Diehl AM. Nonalcoholic steatohepatitis. Annu Rev Med. (2017) 68:85-98. doi: 10.1146/annurev-med-051215-031109

3. Cotter TG, Rinella M. NAFLD 2020: the state of the disease. Gastroenterology. (2020) 158:1851-64. doi: 10.1053/j.gastro.2020.01.052

4. Manne V, Handa P, Kowdley KV. Pathophysiology of nonalcoholic fatty liver disease/nonalcoholic steatohepatitis. Clin Liver Dis. (2018) 22:23-37. doi: 10.1016/j.cld.2017.08.007

5. Febbraio MA, Reibe S, Shalapour S, Ooi GJ, Watt MJ, Karin M. Preclinical models for studying NASH-driven HCC: how useful are they? Cell Metab. (2019) 29:18-26. doi: 10.1016/j.cmet.2018.10.012

6. Liu W, Baker RD, Bhatia T, Zhu L, Baker SS. Pathogenesis of nonalcoholic steatohepatitis. Cell Mol Life Sci. (2016) 73:1969-87. doi: 10.1007/s00018-016-2161-x

7. Vernon G, Baranova A, Younossi ZM. Systematic review: the epidemiology and natural history of non-alcoholic fatty liver disease and nonalcoholic steatohepatitis in adults. Aliment Pharmacol Ther. (2011) 34:274-85. doi: 10.1111/j.1365-2036.2011.04724.x

8. Fan JG, Kim SU, Wong VW. New trends on obesity and NAFLD in Asia. $J$ Hepatol. (2017) 67:862-73. doi: 10.1016/j.jhep.2017.06.003

9. Younossi ZM, Golabi P, de Avila L, Paik JM, Srishord M, Fukui N, et al. The global epidemiology of NAFLD and NASH in patients with type 2 diabetes: a systematic review and meta-analysis. J Hepatol. (2019) 71:793-801. doi: 10.1016/j.jhep.2019.06.021

10. Schuster S, Cabrera D, Arrese M, Feldstein AE. Triggering and resolution of inflammation in NASH. Nat Rev Gastroenterol Hepatol. (2018) 15:349-64. doi: 10.1038/s41575-018-0009-6

11. Marra F, Svegliati-Baroni G. Lipotoxicity and the gut-liver axis in NASH pathogenesis. J Hepatol. (2018) 68:280-95. doi: 10.1016/j.jhep.2017.11.014

12. Armstrong MJ, Adams LA, Canbay A, Syn WK. Extrahepatic complications of nonalcoholic fatty liver disease. Hepatology. (2014) 59:1174-97. doi: 10.1002/hep.26717

13. Cai J, Zhang XJ, Li H. The role of innate immune cells in nonalcoholic steatohepatitis. Hepatology. (2019) 70:1026-37. doi: 10.1002/hep.30506

14. Sundaresan S, Vijayagopal P, Mills N, Imrhan V, Prasad C. A mouse model for nonalcoholic steatohepatitis. J Nutr Biochem. (2011) 22:979-84. doi: 10.1016/j.jnutbio.2010.08.011

15. Kohli R, Kirby M, Xanthakos SA, Softic S, Feldstein AE, Saxena V, et al. High-fructose, medium chain trans fat diet induces liver fibrosis and elevates plasma coenzyme Q9 in a novel murine model of obesity and nonalcoholic steatohepatitis. Hepatology. (2010) 52:934-44. doi: 10.1002/hep.23797

16. Savard C, Tartaglione EV, Kuver R, Haigh WG, Farrell GC, Subramanian $\mathrm{S}$, et al. Synergistic interaction of dietary cholesterol and dietary fat in inducing experimental steatohepatitis. Hepatology. (2013) 57:81-92. doi: 10.1002/hep.25789

\section{AUTHOR CONTRIBUTIONS}

YC prepared the manuscript, table, and figures. ZT designed and gave guidance on the outline, and revised the manuscript. All authors contributed to the article and approved the submitted version.

\section{FUNDING}

This work was supported by National Natural Science Foundation of China (Grant Nos. 81788101, 91542000, 91842307).

17. Charlton M, Krishnan A, Viker K, Sanderson S, Cazanave S, McConico A, et al. Fast food diet mouse: novel small animal model of NASH with ballooning, progressive fibrosis, and high physiological fidelity to the human condition. Am J Physiol Gastrointest Liver Physiol. (2011) 301:G825-34. doi: 10.1152/ajpgi.00145.2011

18. Asgharpour A, Cazanave SC, Pacana T, Seneshaw M, Vincent R, Banini BA, et al. A diet-induced animal model of non-alcoholic fatty liver disease and hepatocellular cancer. J Hepatol. (2016) 65:579-88. doi: 10.1016/j.jhep.2016.05.005

19. Rinella ME, Elias MS, Smolak RR, Fu T, Borensztajn J, Green RM. Mechanisms of hepatic steatosis in mice fed a lipogenic methionine choline-deficient diet. J Lipid Res. (2008) 49:1068-76. doi: 10.1194/jlr.M800042-JLR200

20. Rinella ME, Green RM. The methionine-choline deficient dietary model of steatohepatitis does not exhibit insulin resistance. J Hepatol. (2004) 40:47-51. doi: 10.1016/j.jhep.2003.09.020

21. Wolf MJ, Adili A, Piotrowitz K, Abdullah Z, Boege Y, Stemmer K, et al. Metabolic activation of intrahepatic CD8 $+\mathrm{T}$ cells and NKT cells causes nonalcoholic steatohepatitis and liver cancer via cross-talk with hepatocytes. Cancer Cell. (2014) 26:549-64. doi: 10.1016/j.ccell.2014.09.003

22. Widjaja AA, Singh BK, Adami E, Viswanathan S, Dong J, D’Agostino $\mathrm{GA}$, et al. Inhibiting interleukin 11 signaling reduces hepatocyte death and liver fibrosis, inflammation, and steatosis in mouse models of nonalcoholic steatohepatitis. Gastroenterology. (2019) 157:777-92. doi: 10.1053/j.gastro.2019.05.002

23. Tsuchida T, Lee YA, Fujiwara N, Ybanez M, Allen B, Martins S, et al. A simple diet- and chemical-induced murine NASH model with rapid progression of steatohepatitis, fibrosis and liver cancer. J Hepatol. (2018) 69:385-95. doi: 10.1016/j.jhep.2018.03.011

24. Fujii M, Shibazaki Y, Wakamatsu K, Honda Y, Kawauchi Y, Suzuki K, et al. A murine model for non-alcoholic steatohepatitis showing evidence of association between diabetes and hepatocellular carcinoma. $\mathrm{Med} \mathrm{Mol}$ Morphol. (2013) 46:141-52. doi: 10.1007/s00795-013-0016-1

25. Saito T, Muramatsu M, Ishii Y, Saigo Y, Konuma T, Toriniwa Y, et al. Pathophysiological analysis of the progression of hepatic lesions in STAM mice. Physiol Res. (2017) 66:791-9. doi: 10.33549/physiolres.933592

26. Horie Y, Suzuki A, Kataoka E, Sasaki T, Hamada K, Sasaki J, et al. Hepatocytespecific Pten deficiency results in steatohepatitis and hepatocellular carcinomas. J Clin Invest. (2004) 113:1774-83. doi: 10.1172/JCI20513

27. Polyzos SA, Kountouras J, Mantzoros CS. Leptin in nonalcoholic fatty liver disease: a narrative review. Metabolism. (2015) 64:60-78. doi: 10.1016/j.metabol.2014.10.012

28. Trak-Smayra V, Paradis V, Massart J, Nasser S, Jebara V, Fromenty B. Pathology of the liver in obese and diabetic ob/ob and $\mathrm{db} / \mathrm{db}$ mice fed a standard or high-calorie diet. Int J Exp Pathol. (2011) 92:413-21. doi: 10.1111/j.1365-2613.2011.00793.x

29. Martinez-Chantar ML, Vazquez-Chantada M, Ariz U, Martinez N, Varela M, Luka Z, et al. Loss of the glycine N-methyltransferase gene leads to steatosis and hepatocellular carcinoma in mice. Hepatology. (2008) 47:1191-9. doi: 10.1002/hep.22159 
30. Itoh $M$, Suganami $T$, Nakagawa $N$, Tanaka $M$, Yamamoto $Y$, Kamei Y, et al. Melanocortin 4 receptor-deficient mice as a novel mouse model of nonalcoholic steatohepatitis. Am J Pathol. (2011) 179:2454-63. doi: 10.1016/j.ajpath.2011.07.014

31. Gandhi CR, Chaillet JR, Nalesnik MA, Kumar S, Dangi A, Demetris AJ, et al. Liver-specific deletion of augmenter of liver regeneration accelerates development of steatohepatitis and hepatocellular carcinoma in mice. Gastroenterology. (2015) 148:379-91. doi: 10.1053/j.gastro.2014.10.008

32. Bieghs V, Van Gorp PJ, Wouters K, Hendrikx T, Gijbels MJ, van Bilsen M, et al. LDL receptor knock-out mice are a physiological model particularly vulnerable to study the onset of inflammation in non-alcoholic fatty liver disease. PLoS ONE. (2012) 7:e30668. doi: 10.1371/journal.pone.0030668

33. Shiri-Sverdlov R, Wouters K, van Gorp PJ, Gijbels MJ, Noel B, Buffat L, et al. Early diet-induced non-alcoholic steatohepatitis in APOE2 knock-in mice and its prevention by fibrates. J Hepatol. (2006) 44:732-41. doi: 10.1016/j.jhep.2005.10.033

34. Nakagawa H, Umemura A, Taniguchi K, Font-Burgada J, Dhar D, Ogata $\mathrm{H}$, et al. ER stress cooperates with hypernutrition to trigger TNF-dependent spontaneous HCC development. Cancer Cell. (2014) 26:331-43. doi: 10.1016/j.ccr.2014.07.001

35. Mokhtari Z, Gibson DL, Hekmatdoost A. Nonalcoholic fatty liver disease, the gut microbiome, and diet. Adv Nutr. (2017) 8:240-52. doi: 10.3945/an.116.013151

36. Hildebrandt MA, Hoffmann C, Sherrill-Mix SA, Keilbaugh SA, Hamady M, Chen YY, et al. High-fat diet determines the composition of the murine gut microbiome independently of obesity. Gastroenterology. (2009) 137:1716-24. doi: 10.1053/j.gastro.2009.08.042

37. Corbin $\mathrm{KD}$, Zeisel SH. Choline metabolism provides novel insights into nonalcoholic fatty liver disease and its progression. Curr Opin Gastroenterol. (2012) 28:159-65. doi: 10.1097/MOG.0b013e32834e7b4b

38. Sherriff JL, O'Sullivan TA, Properzi C, Oddo JL, Adams LA. Choline, its potential role in nonalcoholic fatty liver disease, and the case for human and bacterial genes. Adv Nutr. (2016) 7:5-13. doi: 10.3945/an.114. 007955

39. Spencer MD, Hamp TJ, Reid RW, Fischer LM, Zeisel SH, Fodor AA. Association between composition of the human gastrointestinal microbiome and development of fatty liver with choline deficiency. Gastroenterology. (2011) 140:976-86. doi: 10.1053/j.gastro.2010.11.049

40. Buchman AL. Complications of long-term home total parenteral nutrition: their identification, prevention and treatment. Dig Dis Sci. (2001) 46:1-18. doi: 10.1023/a:1005628121546

41. Machado MV, Michelotti GA, Xie G, Almeida Pereira T, Boursier J, Bohnic B, et al. Mouse models of diet-induced nonalcoholic steatohepatitis reproduce the heterogeneity of the human disease. PLOS ONE. (2015) 10:e0127991. doi: 10.1371/journal.pone.0127991

42. Ibusuki R, Uto H, Arima S, Mawatari S, Setoguchi Y, Iwashita Y, et al. Transgenic expression of human neutrophil peptide-1 enhances hepatic fibrosis in mice fed a choline-deficient, L-amino acid-defined diet. Liver Int. (2013) 33:1549-56. doi: 10.1111/liv.12203

43. Itagaki H, Shimizu K, Morikawa S, Ogawa K, Ezaki T. Morphological and functional characterization of non-alcoholic fatty liver disease induced by a methionine-choline-deficient diet in C57BL/6 mice. Int J Clin Exp Pathol. (2013) 6:2683-96.

44. Afrin MR, Arumugam S, Rahman MA, Karuppagounder V, Harima M, Suzuki $\mathrm{H}$, et al. Curcumin reduces the risk of chronic kidney damage in mice with nonalcoholic steatohepatitis by modulating endoplasmic reticulum stress and MAPK signaling. Int Immunopharmacol. (2017) 49:161-7. doi: 10.1016/j.intimp.2017.05.035

45. S. De Minicis, Agostinelli L, Rychlicki C, Sorice GP, Saccomanno S, Candelaresi C, et al. HCC development is associated to peripheral insulin resistance in a mouse model of NASH. PLOS ONE. (2014) 9:e97136. doi: 10.1371/journal.pone.0097136

46. Handa P, Morgan-Stevenson V, Maliken BD, Nelson JE, Washington S, Westerman $\mathrm{M}$, et al. Iron overload results in hepatic oxidative stress, immune cell activation, and hepatocellular ballooning injury, leading to nonalcoholic steatohepatitis in genetically obese mice. Am J Physiol Gastrointest Liver Physiol. (2016) 310:G117-27. doi: 10.1152/ajpgi.00 246.2015
47. Watanabe S, Horie Y, Suzuki A. Hepatocyte-specific Pten-deficient mice as a novel model for nonalcoholic steatohepatitis and hepatocellular carcinoma. Hepatol Res. (2005) 33:161-6. doi: 10.1016/j.hepres.2005.09.026

48. Gomez-Santos L, Luka Z, Wagner C, Fernandez-Alvarez S, Lu SC, Mato $\mathrm{JM}$, et al. Inhibition of natural killer cells protects the liver against acute injury in the absence of glycine N-methyltransferase. Hepatology. (2012) 56:747-59. doi: 10.1002/hep.25694

49. Kumar S, Verma AK, Rani R, Sharma A, Wang J, Shah SA, et al. Hepatic deficiency of augmenter of liver regeneration predisposes to nonalcoholic steatohepatitis and fibrosis. Hepatology. (2020). doi: 10.1002/hep.31167. [Epub ahead of print].

50. Vivier E, Artis D, Colonna M, Diefenbach A, Di Santo JP, Eberl G, et al. Innate lymphoid cells: 10 years on. Cell. (2018) 174:1054-66. doi: 10.1016/j.cell.2018.07.017. [Epub ahead of print].

51. Wang X, Peng H, Tian Z. Innate lymphoid cell memory. Cell Mol Immunol. (2019) 16:423-9. doi: 10.1038/s41423-019-0212-6

52. Kansler ER, Li MO. Innate lymphocytes-lineage, localization and timing of differentiation. Cell Mol Immunol. (2019) 16:627-33. doi: 10.1038/s41423-019-0211-7

53. Seillet $C$, Jacquelot N. Sensing of physiological regulators by innate lymphoid cells. Cell Mol Immunol. (2019) 16:442-51. doi: 10.1038/s41423-019-0217-1

54. Klose CSN, Flach M, Mohle L, Rogell L, Hoyler T, Ebert K, et al. Differentiation of type 1 ILCs from a common progenitor to all helper-like innate lymphoid cell lineages. Cell. (2014) 157:340-56. doi: 10.1016/j.cell.2014.03.030

55. Yu Y, Tsang JC, Wang C, Clare S, Wang J, Chen X, et al. Single-cell RNA-seq identifies a PD-1(hi) ILC progenitor and defines its development pathway. Nature. (2016) 539:102-6. doi: 10.1038/nature20105

56. Lim AI, J.P. Di Santo, ILC-poiesis: ensuring tissue ILC differentiation at the right place and time. Eur J Immunol. (2019) 49:11-8. doi: 10.1002/eji.201747294

57. Zhou J, Tian Z, Peng H. Tissue-resident NK cells and other innate lymphoid cells. Adv Immunol. (2020) 145:37-53. doi: 10.1016/bs.ai.2019.11.002

58. Chen Y, Tian Z, Peng H. Immunological memory: ILC1s come into view. Cell Mol Immunol. (2019) 16:895-6. doi: 10.1038/s41423-019-0311-4

59. Shi FD, Ljunggren HG, La Cava A, Van Kaer L. Organ-specific features of natural killer cells. Nat Rev Immunol. (2011) 11:658-71. doi: 10.1038/nri3065

60. Peng H, Tian Z. NK cells in liver homeostasis and viral hepatitis. Sci China Life Sci. (2018) 61:1477-85. doi: 10.1007/s11427-018-9407-2

61. Sivori S, Vacca P, Del Zotto G, Munari E, Mingari MC, Moretta L. Human NK cells: surface receptors, inhibitory checkpoints, translational applications. Cell Mol Immunol. (2019) 16:430-41. doi: 10.1038/s41423-019-0206-4

62. Tosello-Trampont AC, Krueger P, Narayanan S, Landes SG, Leitinger N, Hahn YS. NKp46(+) natural killer cells attenuate metabolism-induced hepatic fibrosis by regulating macrophage activation in mice. Hepatology. (2016) 63:799-812. doi: 10.1002/hep.28389

63. Fan Y, Zhang W, Wei H, Sun R, Tian Z, Chen Y. Hepatic NK cells attenuate fibrosis progression of non-alcoholic steatohepatitis in dependent of CXCL10-mediated recruitment. Liver Int. (2020) 40:598-608. doi: 10.1111/liv.14307

64. Cepero-Donates Y, Lacraz G, Ghobadi F, Rakotoarivelo V, Orkhis $\mathrm{S}$, Mayhue $\mathrm{M}$, et al. Interleukin-15-mediated inflammation promotes non-alcoholic fatty liver disease. Cytokine. (2016) 82:102-11. doi: 10.1016/j.cyto.2016.01.020

65. Tian Z, Sun R, Wei H, Gao B. Impaired natural killer (NK) cell activity in leptin receptor deficient mice: leptin as a critical regulator in NK cell development and activation. Biochem Biophys Res Commun. (2002) 298:297-302. doi: 10.1016/S0006-291X(02)02462-2

66. Daussy C, Faure F, Mayol K, Viel S, Gasteiger G, Charrier E, et al. Tbet and Eomes instruct the development of two distinct natural killer cell lineages in the liver and in the bone marrow. J Exp Med. (2014) 211:563-77. doi: 10.1084/jem.20131560

67. Weizman OE, Adams NM, Schuster IS, Krishna C, Pritykin Y, Lau C, et al. ILC1 confer early host protection at initial sites of viral infection. Cell. (2017) 171:795-808. doi: 10.1016/j.cell.2017.09.052

68. Wensveen FM, Jelencic V, Valentic S, Sestan M, Wensveen TT, Theurich $\mathrm{S}$, et al. NK cells link obesity-induced adipose stress to inflammation and insulin resistance. Nat Immunol. (2015) 16:376-85. doi: 10.1038/ni.3120 
69. O’Sullivan TE, Rapp M, Fan X, Weizman OE, Bhardwaj P, Adams NM, et al. Adipose-resident group 1 innate lymphoid cells promote obesity-associated insulin resistance. Immunity. (2016) 45:428-41. doi: 10.1016/j.immuni.2016.06.016

70. Boulenouar S, Michelet X, Duquette D, Alvarez D, Hogan AE, Dold C, et al. Adipose type one innate lymphoid cells regulate macrophage homeostasis through targeted cytotoxicity. Immunity. (2017) 46:273-86. doi: 10.1016/j.immuni.2017.01.008

71. Gao Y, Souza-Fonseca-Guimaraes F, Bald T, Ng SS, Young A, Ngiow $\mathrm{SF}$, et al. Tumor immunoevasion by the conversion of effector NK cells into type 1 innate lymphoid cells. Nat Immunol. (2017) 18:1004-15. doi: 10.1038/ni.3800

72. Cuff AO, Sillito F, Dertschnig S, Hall A, Luong TV, Chakraverty $\mathrm{R}$, et al. The obese liver environment mediates conversion of $\mathrm{NK}$ cells to a less cytotoxic ILC1-like phenotype. Front Immunol. (2019) 10:2180. doi: 10.3389/fimmu.2019.02180

73. Michelet X, Dyck L, Hogan A, Loftus RM, Duquette D, Wei $\mathrm{K}$, et al. Metabolic reprogramming of natural killer cells in obesity limits antitumor responses. Nat Immunol. (2018) 19:1330-40. doi: 10.1038/s41590-018-0251-7

74. Zhang X, Shen J, Man K, Chu ES, Yau TO, Sung JC, et al. CXCL10 plays a key role as an inflammatory mediator and a non-invasive biomarker of non-alcoholic steatohepatitis. J Hepatol. (2014) 61:1365-75. doi: 10.1016/j.jhep.2014.07.006

75. Bertola A, Bonnafous S, Anty R, Patouraux S, Saint-Paul MC, Iannelli A, et al. Hepatic expression patterns of inflammatory and immune response genes associated with obesity and NASH in morbidly obese patients. PLoS ONE. (2010) 5:e13577. doi: 10.1371/journal.pone.0013577

76. Stiglund N, Strand K, Cornillet M, Stal P, Thorell A, Zimmer CL, et al. Retained NK cell phenotype and functionality in non-alcoholic fatty liver disease. Front Immunol. (2019) 10:1255. doi: 10.3389/fimmu.2019.01255

77. Kahraman A, Schlattjan M, Kocabayoglu P, Yildiz-Meziletoglu S, Schlensak M, Fingas CD, et al. Major histocompatibility complex class I-related chains A and B (MIC A/B): a novel role in nonalcoholic steatohepatitis. Hepatology. (2010) 51:92-102. doi: 10.1002/hep.23253

78. Viel S, Besson L, Charrier E, Marcais A, Disse E, Bienvenu J, et al. Alteration of natural killer cell phenotype and function in obese individuals. Clin Immunol. (2017) 177:12-7. doi: 10.1016/j.clim.2016.01.007

79. Marquardt N, Béziat V, Nyström S, Hengst J, Ivarsson MA, Kekäläinen E, et al. Cutting edge: identification and characterization of human intrahepatic CD49a+ NK cells. J. Immunol. (2015) 194:2467-71. doi: 10.4049/jimmunol.1402756

80. Aw Yeang HX, Piersma SJ, Lin Y, Yang L, Malkova ON, Miner C, et al. Cutting edge: human CD49e- NK cells are tissue resident in the liver. $J$ Immunol. (2017) 198:1417-22. doi: 10.4049/jimmunol.1601818

81. Stegmann KA, Robertson F, Hansi N, Gill U, Pallant C, Christophides T, et al. CXCR6 marks a novel subset of T-bet(lo)Eomes(hi) natural killer cells residing in human liver. Sci Rep. (2016) 6:26157. doi: 10.1038/srep26157

82. Sun H, Sun C, Xiao W, Sun R. Tissue-resident lymphocytes: from adaptive to innate immunity. Cell Mol Immunol. (2019) 16:205-15. doi: 10.1038/s41423-018-0192-y

83. Gurram RK, Zhu J. Orchestration between ILC2s and Th2 cells in shaping type 2 immune responses. Cell Mol Immunol. (2019) 16:225-35. doi: 10.1038/s41423-019-0210-8

84. Germain RN, Huang Y. ILC2s - resident lymphocytes pre-adapted to a specific tissue or migratory effectors that adapt to where they move? Curr Opin Immunol. (2019) 56:76-81. doi: 10.1016/j.coi.2018. 11.001

85. Forkel M, Berglin L, Kekalainen E, Carlsson A, Svedin E, Michaelsson J, et al. Composition and functionality of the intrahepatic innate lymphoid cell-compartment in human nonfibrotic and fibrotic livers. Eur J Immunol. (2017) 47:1280-94. doi: 10.1002/eji.201646890

86. McHedlidze T, Waldner M, Zopf S, Walker J, Rankin AL, Schuchmann $\mathrm{M}$, et al. Interleukin-33-dependent innate lymphoid cells mediate hepatic fibrosis. Immunity. (2013) 39:357-71. doi: 10.1016/j.immuni.2013.07.018

87. Tan Z, Liu Q, Jiang R, Lv L, Shoto SS, Maillet I, et al. Interleukin-33 drives hepatic fibrosis through activation of hepatic stellate cells. Cell Mol Immunol. (2018) 15:388-98. doi: $10.1038 / \mathrm{cmi} .2016 .63$
88. Brestoff JR, Kim BS, Saenz SA, Stine RR, Monticelli LA, Sonnenberg GF, et al. Group 2 innate lymphoid cells promote beiging of white adipose tissue and limit obesity. Nature. (2015) 519:242-6. doi: 10.1038/nature14115

89. Lee MW, Odegaard JI, Mukundan L, Qiu Y, Molofsky AB, Nussbaum JC, et al. Activated type 2 innate lymphoid cells regulate beige fat biogenesis. Cell. (2015) 160:74-87. doi: 10.1016/j.cell.2014.12.011

90. Wang S, Li J, Wu S, Cheng L, Shen Y, Ma W, et al. Type 3 innate lymphoid cell: a new player in liver fibrosis progression. Clin Sci. (2018) 132:2565-82. doi: 10.1042/CS20180482

91. Radaeva S, Sun R, Pan HN, Hong F, Gao B. Interleukin 22 (IL-22) plays a protective role in T cell-mediated murine hepatitis: IL-22 is a survival factor for hepatocytes via STAT3 activation. Hepatology. (2004) 39:1332-42. doi: 10.1002/hep.20184

92. Park O, Wang $\mathrm{H}$, Weng $\mathrm{H}$, Feigenbaum L, Li $\mathrm{H}$, Yin $\mathrm{S}$, et al. In vivo consequences of liver-specific interleukin-22 expression in mice: implications for human liver disease progression. Hepatology. (2011) 54:252-61. doi: 10.1002/hep.24339

93. Zenewicz LA, Yancopoulos GD, Valenzuela DM, Murphy AJ, Karow M, Flavell RA. Interleukin-22 but not interleukin-17 provides protection to hepatocytes during acute liver inflammation. Immunity. (2007) 27:647-59. doi: 10.1016/j.immuni.2007.07.023

94. Wang X, Ota N, Manzanillo P, Kates L, Zavala-Solorio J, Eidenschenk C, et al. Interleukin-22 alleviates metabolic disorders and restores mucosal immunity in diabetes. Nature. (2014) 514:237-41. doi: 10.1038/nature13564

95. Marrero I, Maricic I, Feldstein AE, Loomba R, Schnabl B, Rivera-Nieves J, et al. Complex network of NKT cell subsets controls immune homeostasis in liver and gut. Front Immunol. (2018) 9:2082. doi: 10.3389/fimmu.2018.02082

96. Miyagi T, Takehara T, Uemura A, Nishio K, Shimizu S, Kodama T, et al. Absence of invariant natural killer $\mathrm{T}$ cells deteriorates liver inflammation and fibrosis in mice fed high-fat diet. J Gastroenterol. (2010) 45:1247-54. doi: 10.1007/s00535-010-0272-y

97. Martin-Murphy BV, You Q, Wang H, De La Houssaye BA, Reilly TP, Friedman JE, et al. Mice lacking natural killer T cells are more susceptible to metabolic alterations following high fat diet feeding. PLoS ONE. (2014) 9:e80949. doi: 10.1371/journal.pone.0080949

98. Li Z, Soloski MJ, Diehl AM. Dietary factors alter hepatic innate immune system in mice with nonalcoholic fatty liver disease. Hepatology. (2005) 42:880-5. doi: 10.1002/hep.20826

99. Kremer M, Thomas E, Milton RJ, Perry AW, van Rooijen N, Wheeler MD, et al. Kupffer cell and interleukin-12-dependent loss of natural killer T cells in hepatosteatosis. Hepatology. (2010) 51:130-41. doi: 10.1002/hep.23292

100. Tang ZH, Liang S, Potter J, Jiang X, Mao HQ, Li Z. Tim-3/galectin9 regulate the homeostasis of hepatic NKT cells in a murine model of nonalcoholic fatty liver disease. J Immunol. (2013) 190:1788-96. doi: 10.4049/jimmunol.1202814

101. Du X, Wu Z, Xu Y, Liu Y, Liu W, Wang $T$, et al. Increased Tim-3 expression alleviates liver injury by regulating macrophage activation in MCD-induced NASH mice. Cell Mol Immunol. (2019) 16:878-86. doi: 10.1038/s41423-018-0032-0

102. Zhang H, Xue R, Zhu S, Fu S, Chen Z, Zhou R, et al. M2-specific reduction of CD1d switches NKT cell-mediated immune responses and triggers metaflammation in adipose tissue. Cell Mol Immunol. (2018) 15:506-17. doi: 10.1038/cmi.2017.11

103. Syn WK, Oo YH, Pereira TA, Karaca GF, Jung Y, Omenetti A, et al. Accumulation of natural killer $\mathrm{T}$ cells in progressive nonalcoholic fatty liver disease. Hepatology. (2010) 51:1998-2007. doi: 10.1002/hep.23599

104. Sutti S, Jindal A, Locatelli I, Vacchiano M, Gigliotti L, Bozzola $\mathrm{C}$, et al. Adaptive immune responses triggered by oxidative stress contribute to hepatic inflammation in NASH. Hepatology. (2014) 59:886-97. doi: 10.1002/hep.26749

105. Syn WK, Agboola KM, Swiderska M, Michelotti GA, Liaskou $\mathrm{E}$, Pang $\mathrm{H}$, et al. NKT-associated hedgehog and osteopontin drive fibrogenesis in non-alcoholic fatty liver disease. Gut. (2012) 61:1323-9. doi: 10.1136/gutjnl-2011-301857

106. Maricic I, Marrero I, Eguchi A, Nakamura R, Johnson CD, Dasgupta S, et al. Differential activation of hepatic invariant NKT cell subsets plays a key role in progression of nonalcoholic steatohepatitis. J Immunol. (2018) 201:3017-35. doi: 10.4049/jimmunol.1800614 
107. Bhattacharjee J, Kirby M, Softic S, Miles L, Salazar-Gonzalez RM, Shivakumar P, et al. Hepatic natural killer T-cell and CD8+ T-cell signatures in mice with nonalcoholic steatohepatitis. Hepatol Commun. (2017) 1:299-310. doi: 10.1002/hep4.1041

108. Adler M, Taylor S, Okebugwu K, Yee H, Fielding C, Fielding $\mathrm{G}$, et al. Intrahepatic natural killer $\mathrm{T}$ cell populations are increased in human hepatic steatosis. World J Gastroenterol. (2011) 17:1725-31. doi: 10.3748/wjg.v17.i13.1725

109. Racanelli V, Rehermann B. The liver as an immunological organ. Hepatology. (2006) 43:S54-62. doi: 10.1002/hep.21060

110. Li F, Hao X, Chen Y, Bai L, Gao X, Lian Z, et al. The microbiota maintain homeostasis of liver-resident gammadeltaT-17 cells in a lipid antigen/CD1d-dependent manner. Nat Commun. (2017) 7:13839. doi: $10.1038 /$ ncomms 13839

111. Mehta P, Nuotio-Antar AM, Smith CW. gammadelta T cells promote inflammation and insulin resistance during high fat diet-induced obesity in mice. J Leukoc Biol. (2015) 97:121-34. doi: 10.1189/jlb.3A0414211RR

112. Torres-Hernandez A, Wang W, Nikiforov Y, Tejada K, Torres L, Kalabin A, et al. gammadelta $\mathrm{T}$ cells promote steatohepatitis by orchestrating innate and adaptive immune programming. Hepatology. (2020) 71:477-94. doi: 10.1002/hep.30952

113. Wang $\mathrm{X}$, Gao B. gammadeltaT cells and CD1d, novel immune players in alcoholic and nonalcoholic steatohepatitis? Hepatology. (2020) 71:408-10. doi: 10.1002/hep.31025

114. Hunter S, Willcox CR, Davey MS, Kasatskaya SA, Jeffery HC, Chudakov $\mathrm{DM}$, et al. Human liver infiltrating gammadelta $\mathrm{T}$ cells are composed of clonally expanded circulating and tissue-resident populations. J Hepatol. (2018) 69:654-65. doi: 10.1016/j.jhep.2018.05.007

115. Kenna T, Golden-Mason L, Norris S, Hegarty JE, O'Farrelly C, Doherty DG. Distinct subpopulations of gamma delta $\mathrm{T}$ cells are present in normal and tumor-bearing human liver. Clin Immunol. (2004) 113:56-63. doi: 10.1016/j.clim.2004.05.003

116. Mangan BA, Dunne MR, O’Reilly VP, Dunne PJ, Exley MA, O'Shea D, et al. Cutting edge: CD1d restriction and Th1/Th2/Th17 cytokine secretion by human Vdelta3 T cells. J Immunol. (2013) 191:30-4. doi: 10.4049/jimmunol.1300121

117. Bolte FJ, Rehermann B. Mucosal-associated invariant $T$ cells in chronic inflammatory liver disease. Semin Liver Dis. (2018) 38:60-5. doi: 10.1055/s-0037-1621709

118. Magalhaes I, Pingris K, Poitou C, Bessoles S, Venteclef N, Kiaf B, et al. Mucosal-associated invariant $\mathrm{T}$ cell alterations in obese and type 2 diabetic patients. J Clin Invest. (2015) 125:1752-62. doi: 10.1172/JCI78941

119. Bertrand L, Lehuen A. MAIT cells in metabolic diseases. Mol Metab. (2019) 27S:S114-21. doi: 10.1016/j.molmet.2019.06.025

120. Hegde P, Weiss E, Paradis V, Wan J, Mabire M, Sukriti S, et al. Mucosalassociated invariant $\mathrm{T}$ cells are a profibrogenic immune cell population in the liver. Nat Commun. (2018) 9:2146. doi: 10.1038/s41467-018-04450-y

121. Li Y, Huang B, Jiang X, Chen W, Zhang J, Wei Y, et al. Mucosalassociated invariant $\mathrm{T}$ cells improve nonalcoholic fatty liver disease through regulating macrophage polarization. Front Immunol. (2018) 9:1994. doi: 10.3389/fimmu.2018.01994

122. Alkhouri N, Dixon LJ, Feldstein AE. Lipotoxicity in nonalcoholic fatty liver disease: not all lipids are created equal. Expert Rev Gastroenterol Hepatol. (2009) 3:445-51. doi: 10.1586/egh.09.32

123. Farrell GC, Haczeyni F, Chitturi S. Pathogenesis of NASH: how metabolic complications of overnutrition favour lipotoxicity and pro-inflammatory fatty liver disease. Adv Exp Med Biol. (2018) 1061:19-44. doi: 10.1007/978-981-10-8684-7 3

124. Ramadori P, Kroy D, Streetz KL. Immunoregulation by lipids during the development of non-alcoholic steatohepatitis. Hepatobiliary Surg Nutr. (2015) 4:11-23. doi: 10.3978/j.issn.2304-3881.2015.01.02

125. Malhi H, Gores GJ. Molecular mechanisms of lipotoxicity in nonalcoholic fatty liver disease. Semin Liver Dis. (2008) 28:360-9. doi: 10.1055/s-0028-1091980

126. Ibrahim SH, Hirsova P, Gores GJ. Non-alcoholic steatohepatitis pathogenesis: sublethal hepatocyte injury as a driver of liver inflammation. Gut. (2018) 67:963-72. doi: 10.1136/gutjnl-2017-315691
127. Choi SS, Diehl AM. Hepatic triglyceride synthesis and nonalcoholic fatty liver disease. Curr Opin Lipidol. (2008) 19:295-300. doi: 10.1097/MOL.0b013e3282ff5e55

128. Listenberger LL, Han X, Lewis SE, Cases S, Farese RV, Jr, et al. Triglyceride accumulation protects against fatty acid-induced lipotoxicity. Proc Natl Acad Sci USA. (2003) 100:3077-82. doi: 10.1073/pnas.0630 588100

129. Yamaguchi K, Yang L, McCall S, Huang J, Yu XX, Pandey SK, et al. Inhibiting triglyceride synthesis improves hepatic steatosis but exacerbates liver damage and fibrosis in obese mice with nonalcoholic steatohepatitis. Hepatology. (2007) 45:1366-74. doi: 10.1002/hep.21655

130. Feldstein AE, Werneburg NW, Canbay A, Guicciardi ME, Bronk SF, Rydzewski R, et al. Free fatty acids promote hepatic lipotoxicity by stimulating TNF-alpha expression via a lysosomal pathway. Hepatology. (2004) 40:185-94. doi: 10.1002/hep.20283

131. Puri P, Baillie RA, Wiest MM, Mirshahi F, Choudhury J, Cheung O, et al. A lipidomic analysis of nonalcoholic fatty liver disease. Hepatology. (2007) 46:1081-90. doi: 10.1002/hep.21763

132. Mari M, Caballero F, Colell A, Morales A, Caballeria J, Fernandez A, et al. Mitochondrial free cholesterol loading sensitizes to TNF- and Fas-mediated steatohepatitis. Cell Metab. (2006) 4:185-98. doi: 10.1016/j.cmet.2006. 07.006

133. Csak T, Ganz M, Pespisa J, Kodys K, Dolganiuc A, Szabo G. Fatty acid and endotoxin activate inflammasomes in mouse hepatocytes that release danger signals to stimulate immune cells. Hepatology. (2011) 54:133-44. doi: 10.1002/hep.24341

134. Wei Y, Wang D, Topczewski F, Pagliassotti MJ. Saturated fatty acids induce endoplasmic reticulum stress and apoptosis independently of ceramide in liver cells. Am J Physiol Endocrinol Metab. (2006) 291:E275-81. doi: 10.1152/ajpendo.00644.2005

135. Puri P, Mirshahi F, Cheung O, Natarajan R, Maher JW, Kellum $\mathrm{JM}$, et al. Activation and dysregulation of the unfolded protein response in nonalcoholic fatty liver disease. Gastroenterology. (2008) 134:568-76. doi: 10.1053/j.gastro.2007.10.039

136. Lebeaupin C, Vallee D, Hazari Y, Hetz C, Chevet E, BaillyMaitre B. Endoplasmic reticulum stress signalling and the pathogenesis of non-alcoholic fatty liver disease. J Hepatol. (2018) 69:927-47. doi: 10.1016/j.jhep.2018.06.008

137. Lebeaupin C, Vallee D, Rousseau D, Patouraux S, Bonnafous S, Adam G, et al. Bax inhibitor-1 protects from nonalcoholic steatohepatitis by limiting inositol-requiring enzyme 1 alpha signaling in mice. Hepatology. (2018) 68:515-32. doi: 10.1002/hep.29847

138. Dela Pena A, Leclercq I, Field J, George J, Jones B, Farrell G. NFkappaB activation, rather than TNF, mediates hepatic inflammation in a murine dietary model of steatohepatitis. Gastroenterology. (2005) 129:1663-74. doi: 10.1053/j.gastro.2005.09.004

139. Willy JA, Young SK, Stevens JL, Masuoka HC, Wek RC. CHOP links endoplasmic reticulum stress to NF-kappaB activation in the pathogenesis of nonalcoholic steatohepatitis. Mol Biol Cell. (2015) 26:2190-204. doi: 10.1091/mbc.E15-01-0036

140. Yang L, Jhaveri R, Huang J, Qi Y, Diehl AM. Endoplasmic reticulum stress, hepatocyte CD1d and NKT cell abnormalities in murine fatty livers. Lab Invest. (2007) 87:927-37. doi: 10.1038/labinvest.3700603

141. Govindarajan S, Verheugen E, Venken K, Gaublomme D, Maelegheer $\mathrm{M}$, Cloots E, et al. ER stress in antigen-presenting cells promotes NKT cell activation through endogenous neutral lipids. EMBO Rep. (2020) 21:e48927. doi: 10.15252/embr.201948927

142. Suzuki T, Gao J, Ishigaki Y, Kondo K, Sawada S, Izumi T, et al. ER stress protein CHOP mediates insulin resistance by modulating adipose tissue macrophage polarity. Cell Rep. (2017) 18:2045-57. doi: 10.1016/j.celrep.2017.01.076

143. Berrou J, Fougeray S, Venot M, Chardiny V, Gautier JF, Dulphy N, et al. Natural killer cell function, an important target for infection and tumor protection, is impaired in type 2 diabetes. PLoS ONE. (2013) 8:e62418. doi: 10.1371/journal.pone.0062418

144. Parekh S, Anania FA. Abnormal lipid and glucose metabolism in obesity: implications for nonalcoholic fatty liver disease. Gastroenterology. (2007) 132:2191-207. doi: 10.1053/j.gastro.2007.03.055 
145. Arrese M, Cabrera D, Kalergis AM, Feldstein AE. Innate immunity and inflammation in NAFLD/NASH. Dig Dis Sci. (2016) 61:1294-303. doi: 10.1007/s10620-016-4049-x

146. Estrada SM, Thagard AS, Dehart MJ, Damicis JR, Dornisch EM, Ippolito $\mathrm{DL}$, et al. The orphan nuclear receptor Nr4al mediates perinatal neuroinflammation in a murine model of preterm labor. Cell Death Dis. (2020) 11:11. doi: 10.1038/s41419-019-2196-7

147. Sun X, Seidman JS, Zhao P, Troutman TD, Spann NJ, Que $X$, et al. Neutralization of oxidized phospholipids ameliorates non-alcoholic steatohepatitis. Cell Metab. (2020) 31:189-206. doi: 10.1016/j.cmet.2019.10.014

148. Qi J, Kim JW, Zhou Z, Lim CW, Kim B. Ferroptosis affects the progression of nonalcoholic steatohepatitis via the modulation of lipid peroxidation-mediated cell death in mice. Am J Pathol. (2020) 190:68-81. doi: 10.1016/j.ajpath.2019. 09.011

149. Li X, Wang TX, Huang X, Li Y, Sun T, Zang S, et al. Targeting ferroptosis alleviates methionine-choline deficient (MCD)-diet induced NASH by suppressing liver lipotoxicity. Liver Int. (2020) 40:1378-94. doi: 10.1111/liv.14428

150. Oseini AM, Sanyal AJ. Therapies in non-alcoholic steatohepatitis (NASH). Liver Int. (2017) 37 (Suppl. 1):97-103. doi: 10.1111/liv.13302

151. Harrison SA, Goodman Z, Jabbar A, Vemulapalli R, Younes ZH, Freilich B, et al. A randomized, placebo-controlled trial of emricasan in patients with NASH and F1-F3 fibrosis. J Hepatol. (2020) 72:816-27. doi: 10.1016/j.jhep.2019.11.024

152. Garcia-Tsao G, Bosch J, Kayali Z, Harrison SA, Abdelmalek MF, Lawitz E, et al. Randomized placebo-controlled trial of emricasan for non-alcoholic steatohepatitis-related cirrhosis with severe portal hypertension. J Hepatol. (2020) 72:885-95. doi: 10.1016/j.jhep.2019.12.010

153. Luci C, Vieira E, Perchet T, Gual P, Golub R. Natural killer cells and type 1 innate lymphoid cells are new actors in non-alcoholic fatty liver disease. Front Immunol. (2019) 10:1192. doi: 10.3389/fimmu.2019.01192

154. Takashima S, Ikejima K, Arai K, Yokokawa J, Kon K, Yamashina S, et al. Glycine prevents metabolic steatohepatitis in diabetic KK-Ay mice through modulation of hepatic innate immunity. Am J Physiol Gastrointest Liver Physiol. (2016) 311:G1105-13. doi: 10.1152/ajpgi.00465.2015

Conflict of Interest: The authors declare that the research was conducted in the absence of any commercial or financial relationships that could be construed as a potential conflict of interest.

Copyright $(2020$ Chen and Tian. This is an open-access article distributed under the terms of the Creative Commons Attribution License (CC BY). The use, distribution or reproduction in other forums is permitted, provided the original author(s) and the copyright owner(s) are credited and that the original publication in this journal is cited, in accordance with accepted academic practice. No use, distribution or reproduction is permitted which does not comply with these terms. 